Document downloaded from:

http://hdl.handle.net/10251/78321

This paper must be cited as:

Martinez-Capel, F.; García López, L.; Beyer, M. (2017). Integrating hydrological modelling and ecosystem functioning for environmental flows in climate change scenarios in the Zambezi River (Zambezi Region, Namibia). River Research and Applications. 33(2):258275. doi:10.1002/rra.3058.

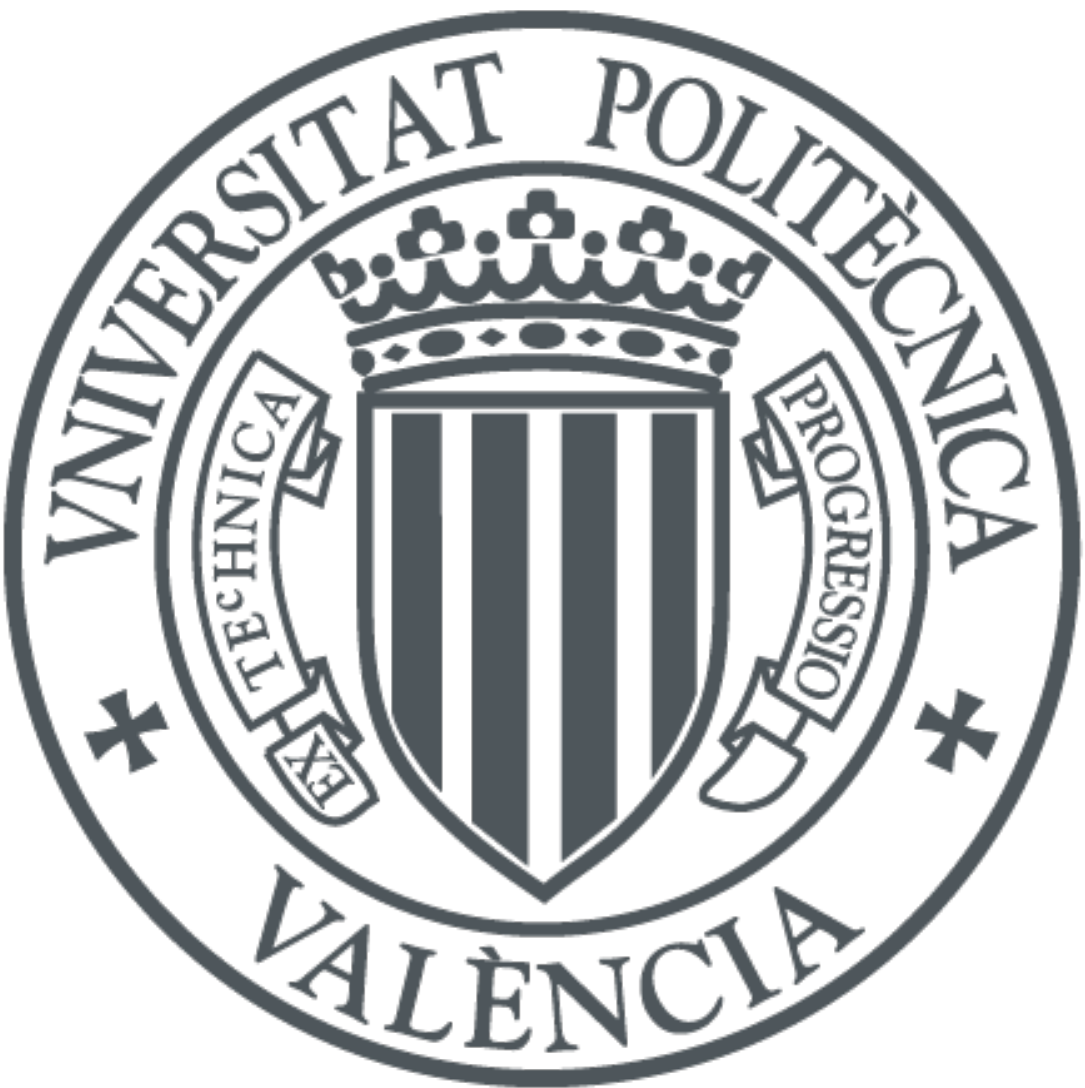

The final publication is available at

http://dx.doi.org/10.1002/rra.3058

Copyright Wiley

Additional Information 


\title{
INTEGRATING HYDROLOGICAL MODELLING AND ECOSYSTEM FUNCTIONING FOR ENVIRONMENTAL FLOWS IN CLIMATE CHANGE SCENARIOS IN THE ZAMBEZI RIVER (ZAMBEZI REGION, NAMIBIA)
}

\author{
FRANCISCO MARTÍNEZ-CAPEL \\ Research Institute for Integrated Management of Coastal Areas (IGIC), Universitat Politècnica de València, C/ \\ Paranimf 1, 46730 Grao de Gandia, Valencia, Spain \\ LUCÍA GARCÍA LÓPEZ \\ Departamento de Ingeniería Hidráulica y Medio Ambiente. (DIHMA).Universidad Politécnica de Valencia. \\ Camino de Vera s/n, 46022, Valencia, Spain \\ MATTHIAS BEYER \\ Institute of Water Resources Management, Hydrology and Agricultural Hydraulic Engineering. Leibniz \\ University Hannover. Appelstrasse 9A. 30167 Hannover, Germany
}

\section{INTRODUCTION}

The ecosystems of our planet are severely threatened by human activities. The development and management of water resources by humans as well as climatic changes have altered the natural flow of rivers around the world, including various components of the flow regime and river habitats. Nowadays, the importance of naturally varying water flows in maintaining river and floodplain health is widely recognized (Matthews and Richter, 2007; Naiman et al., 2008), and Ecosystems and Biodiversity provide a wide range of goods and services (Brauman et al. 2007, Capon et al. 2009, Millennium Ecosystem Assessment, 2005). Thus there is a need for effective instruments to protect river systems from destruction and deterioration.

Within the framework of the CERPA (Certification of Protected Areas) research project and the present study, the wetlands of the Eastern Caprivi were chosen as a pilot study area because of their location at the confluence of the rivers Zambezi, Kwando/Linyanti/Chobe and their unique hydrological and ecologic characteristics. This wetland area provides many Ecosystem Services (ES) that are not only crucial for the local population (e.g. provision of fresh water and fisheries), but also internationally important (e.g. tourism, wildlife); thus the protection of these ES is of great importance. ES is the general name for goods and services provided by ecosystems; benefits which are provided "for free" and normally not assigned a monetary value. Wetland and floodplain ecosystems are known to be highly valuable and therefore provide a wide range of ES; however, there is a great necessity for research involving quantitative studies (Brauman et al., 2007; Carpenter et al., 2009; Nicholson et al., 2009) as well as the development of tools and schemes for a unified evaluation.

The study area comprises four main types of aquatic ecosystems; perennial rivers, mulapos, lakes and streams. Mulapo is the local name for non-permanent lentic water bodies, seasonal depressions receiving water only during the rains and annual flooding; due to the ES they provide, they are amongst the most valuable water bodies (Tvedten, 1994). During the wet season they host (partly) protected fisheries, particularly important in developing countries as the most important source of animal protein for rural communities; and some fish species find habitats for reproduction in these standing waters. However, some wetlands and lakes in Africa are economically overfished (Weyl et al. 2010), and fish communities are changing due to the replacement of some species by smaller, much less valuable species (Weyl et al., 2010; Peel et al. 2013). The wetlands also provide food (fish, wild game, fruits and grain), fresh water, fibre, 
fuel, biochemical (e.g. medicines) and genetic material (genes for resistance to plant pathogens, etc.). During the dry season, when the water recedes, mulapos provide the opportunity for local people to use the water for grazing and agricultural purposes, using the residual soil moisture. The maintenance of annual periods of inundation is fundamental to ensure the provision of benefits from ES. Therefore, it is necessary to establish an environmental flow regime in order to safeguard from the possibility of floods, maintain wetlands and keep the dynamics of the river-floodplain ecosystem in the Eastern Caprivi alive.

Among the various approaches, the holistic methods for environmental flow assessment (EFA) were mainly developed in South Africa and Australia, where the emphasis was on ensuring the protection of entire rivers and their often poorly known biota (Tharme, 2003). However, in other countries, with scarce ecological data, the application of holistic methods can be costly. For instance, it has been reported that many government entities are unable (or unwilling) to afford the cost of applying the ELOHA approach (generally ranging from $\$ 100 \mathrm{k}$ to $\$ 2 \mathrm{M}$ ), especially in situations where existing biological data and hydrological models have poor spatial coverage (Richter et al., 2012). On the contrary, hydrological methods such as the Range of Variability Approach (RVA) have been intensively applied in various countries (Tharme, 2003) and provide a comprehensive statistical characterization of ecologically relevant features of flow regimes (Richter et al., 1997). Furthermore, several researchers consider RVA to be a holistic or ecologically-based (Arthington, 1998; Bragg et al., 1999) approach.

In the present study, RVA was applied due to its ecological significance, limited cost and relatively low data requirements. However, this method does not integrate tools for the spatial analysis of floodplain habitats, which is of great relevance in large wetlands where diverse types of water bodies are present and changes in the water table vary accordingly (for details, see Purvis, 2002). For this reason, an innovative analysis combining hydrological and remote sensing tools was applied to the aquatic habitats; to our knowledge, such analysis has not been applied in EFA before. This is the main methodological innovation of this study, representing a useful approach in extensive areas with scarce ecological field data.

The main objective of this study was to set up the hydrological baseline for the development of environmental flow regimes (EFR) in the wetlands of the Eastern Caprivi. There is no precedent scientific study on the environmental flow regimes in this area, to our knowledge. The specific objectives were; i) the assessment of the fundamental hydrologic parameters, i.e. Environmental Flow Components (EFC), needed to propose EFR in the current near-natural hydrologic conditions; ii) the generation of future scenarios for climatic and socioeconomic changes; iii) the estimation of the area-duration curves and estimated annual habitat during the inundation of the critical habitats for the regional fisheries (mulapos), under the existing conditions and future scenarios; and iv) to provide a framework for the future application of EFRs in the existing conditions and under future scenarios of climatic and socioeconomic changes, based on hydrological and ecological processes in the wetland.

\section{STUDY AREA}

Caprivi (recently renamed Zambezi region) is one of the few regions of Namibia where water scarcity is a minor concern. It has ca. 370,000 ha, of which 220,000 are considered wetland habitats (Turpie, 1999), and it is home to about 110,000 people. Fishing is one of the most important economic activities, including subsistence, commercial and trophy fishing. A total of 
81 fish species occur in the Zambezi system; the most common are the threespot tilapia, greenhead tilapia, redbreast tilapia (Oreochromis and Tilapia spp.), catfish (Clarias spp.), tigerfish (Hydrocynus vittatus) and African pike (Hepsetus odoe) (MFMR 1995, in Thorstad et al., 2001).

This region experiences higher rainfall, less evaporation and warmer winters than any other in Namibia (Mendelsohn, 1997). Climate is semiarid, i.e. there is a wet season (January-June) and a dry season (July-December). Although rains might start in November, heavy rains mainly occur from January to April. The water level in the Zambezi River usually rises sharply in January, with one or more peaks between February and April (Thorstad et al., 2007); the total annual variation in water level is up to 7-8 $\mathrm{m}$ in this area (Van der Waal \& Skelton, 1984). In May, rains usually stop and the water level starts to decline. There is a high variability of river flow in the Zambezi, not only on a monthly, but also an annual basis. Flooding starts when flow is over $1350 \mathrm{~m}^{3} \mathrm{~s}^{-1}$ and river level rises above $7.40 \mathrm{~m}$ (The World Bank, 2010). In extreme years, floodings are so massive that they overrun a subcatchment-boundary in the west of the CapriviChobe floodplain. At these times, water flows through Bukalo Channel into Lake Liambezi; these extreme years are (other than through direct precipitation) the only source of water for this lake, filling it by a much greater magnitude than could be achieved by precipitation (evapotranspiration in Namibia exceeds precipitation) and, in so doing, provides water in sufficient quantity to enable freshwater fishing.

\section{METHODS}

\section{Conceptual framework of flow-biota relationships}

To discuss the influence of the diverse aspects of the river flow regime on the habitats, biota and ecosystem services, it is advisable to develop a conceptual framework of how the river system works. The definition, either qualitative or quantitative, of the linkages between the physical and biological processes is a fundamental step to test, discuss and make assumptions on the potential effects of flow regulation on the biologic processes and the aquatic communities (Souchon et al., 2008). This is a relevant step in any holistic approach for EFA (Arthington et al., 2003; King et al., 2003). However, the actual flow-ecology relations have not been documented in this river. Therefore, it is notable that here we propose a conceptual framework (in linguistic terms) for the influence of river flow on the fish community in the study area; it is based on specific regional information about the fish communities and on the flood pulse concept (Junk et al., 1989) developed in tropical rivers. In the Zambezi river system, the interconnection of the river channel and floodplain is critical because functions such as production, decomposition, and consumption are driven by the flood pulse, as also occurs in other large rivers (see e.g. Sparks et al., 1990).

The conceptual framework is explained herein. During the dry season (July-December), as water recedes, some fish remain isolated in the mulapos, lakes, permanent isolated channels (kasaya) and other habitats in the floodplain until the end of the dry season. Fish accumulate in the low-flow habitats and refuges; there is a high natural mortality in the isolated pools and streams (Purvis, 2002). Some fish species may spawn during this period, e.g. some species of tilapia that raise multiple broods during the warmest months and prefer slow-flowing or standing water such as pools, backwaters and floodplain lagoons (Skelton, 1993). Along with the early rains (usually in December), the water level starts to rise and the upstream migration 
of some fish species starts; the migration period is typically from December to April. Some species of the genus Labeo, Barbus, Hydrocynus, Clarias and Schilbe are considered as longitudinal migrants, spawning during the wet season. During the period of sporadically occurring heavy rains (January-April) the spawning of many fish species coincides with the rising flows and floods, as is common for many species in the tropics (Ikomi, 1996; Kirschbaum \& Schugardt, 2002; McClain, et al., 2014). Thus, the juveniles can be on the floodplain during the wet season and have access to plentiful food supplies (Purvis, 2002). During the wet season, fish are widely dispersed across the floodplains and intensive feeding takes place. Most Namibian fish species (78\%) are floodplain-dependent in the larval and juvenile stages and depend on migration between the floodplains and the main river (Barnard, 1998). Towards the end of the wet season (May-June), as water recedes, the fish move downstream towards the principal river channels; then some fish remain in dry-season habitats. Based on this conceptual framework, the association between the environmental flow components (Table 1) and relevant processes of the fish communities was made, enabling the future design of EFRs.

Table 1

\section{Assessment of EFCs under Existing Condition}

The software IHA (Indices of Hydrological Alteration) for Environmental flows (version 7.1; The Nature Conservancy, 2009) was used to calculate the parameters of five groups of EFCs with non-parametric statistics; low flows, extreme low flows, high-flow pulses, small floods, and large floods (Mathews and Richter, 2007). The only gauging site available was Katima Mulilo, located upstream of the floodplain of Caprivi, in the Zambezi River. The river flow time series comprises the mean daily flow $\left(\mathrm{m}^{3} \mathrm{~s}^{-1}\right)$ from 1943 to 2011 , excluding the years 19551964 (GRDC, 2013). These data were provided by the Department of Water Affairs (DWA) of Namibia, comprising the Existing Condition (EC; nearly natural, not regulated). For the calibration of the EFC algorithm, the standard two-step process was applied (The Nature Conservancy, 2009). Additionally, a trend assessment of the EFCs was performed.

\section{WEAP model for the Caprivi-Chobe floodplains: data, setup and calibration}

The hydrological decision-support-system (DSS) WEAP21 (www.weap21.org) was set up to investigate the impact of climatic and socioeconomic changes on water resources in the CapriviChobe floodplains. The results from this model create the baseline for the research presented here. The model works on a monthly basis and allows for the flexible incorporation of available input data (such as information on flooding extent, socioeconomic development, etc.). Input data used for setting up the model are summarized in Table 2. Before the establishment of the model, an extended hydrological and socioeconomic analysis based on statistical tests and existing studies was conducted. The hydrological analysis comprised; i) trend detection using the non-parametric Mann-Kendall test and, ii) the identification of periodic behaviour using CUSUM and Mann-Whitney tests (for both, see Kundzewicz \& Robson, 2004). These tests were carried out for the variables of precipitation, runoff and temperature. Further statistical analysis on existing runoff data included the creation of flow duration curves, flood frequency analysis and calculation of low-flow statistics (for details, see Beyer \& Billib, 2013). For the validation and interpretation of the data, existing studies were used (World Bank, 2010; Mendelsohn et al., 1997; Tyson et al., 1975). In addition, the observed hydrographs (19432011) were classified into five water year types; very dry, dry, normal, wet and very wet, based on the criteria summarized in Appendix 1. The classification was used for a further analysis of the periodical behaviour by means of frequencies of occurrence and transition probabilities. 
This step was crucial for the analysis and creation of future scenarios, explained in the next section.

\section{Table 2}

The WEAP model was set up for the period 1965-2010 using mean runoff from the classified water year types (not the actual runoff data recorded at Katima Mulilo) as input. Water demands and growth rates were implemented using the data summarized in Table 2. As stated earlier, the best estimates for the different demand sectors were used. It should be acknowledged, however, that data on demands are generally scarce and subject to high uncertainty. The gross amount of water entering the floodplain was determined directly from the flow hydrograph via peak-overthreshold, assuming a threshold of $1350 \mathrm{~m}^{3} / \mathrm{s}$ for the initiation of flooding (World Bank, 2010). The floodplain was treated as a reservoir within WEAP. The volume-elevation curve was derived from the SRTM elevation model and subsequent analysis within GIS.

Subsequently, these data were implemented into the model and water fluxes routed through the model for the calibration period (1965-2010). Observed runoff at the outlet of the catchment was then compared to the modelled results. Due to the particular character of the floodplain (the direction of flow during the rainy season is out of the river, not into the river), no 'classical' hydrological calibration was carried out. Rather, the described procedure allows a validation of the defined criteria for the water year types, as well as of the model input data. Hence, if the model is parameterized correctly, runoff at the outlet should be in good agreement with the observed flow. In Appendix 2, the modelling scheme (redrawn from WEAP21 GUI) is presented. For comparison between observed and modelled flow at Victoria Falls (the catchment outlet) we refer to Beyer \& Billib (2013; available online).

\section{Future scenarios for climatic and socioeconomic changes}

Whenever scenarios are created, just one or a few are often not sufficient. Rather, a variety of scenarios is established and the reality - which is unpredictable - is supposed to be covered by the range of scenarios. This common approach (e.g. IPCC, 2007; Grunewald \& Bastian, 2012) is illustrated in Fig. 1.

\section{Fig. 1}

Based on statistical analysis and the subsequent classification into water year types, a stochastic approach for the creation of future scenarios for climate was developed as follows (Fig.2):

i) Based on the statistical analysis of the past hydro-climate and reports on possible future evolution, a variety of possible future pathways was constructed. For this purpose, the observed relative frequency of occurrence of a certain water year type (within a wet or dry cycle, respectively) was taken and (if assumed in the particular scenario) modified according to the particular scenario. For example, in a scenario where a 5\% increase of extreme events was predicted, the probability for very dry and very wet years was raised in this scenario).

ii) According to the probabilities defined in step i), a random generator was assigned in order to create a sequence of water year types for each climate scenario. The stochastic generation was performed separately for each cycle, i.e. in 18-year intervals (resulting from the statistical analysis, detailed in Appendix 3). That is, if a wet cycle was to be generated, the resampling procedure was repeated until the generated relative frequencies closely matched the relative 
frequency of the wet cycles in the observed series. For the scenarios, where an increased probability of extreme events was assumed, the target probabilities were modified accordingly.

iii) A second random generator was applied to replace the sequence of water year types with the hydrographs from incidentally chosen years of the class of corresponding observed series. That is, if the sequence of water year types is dry - very dry - wet, first any dry year from the observed series is selected and the hydrograph is used; then, a randomly chosen very dry year, then any wet year, and so on.

\section{Fig.2}

The applied stochastic procedure has the advantage that seasonal and annual variability, trends and also cyclic patterns can be represented. Hence possible future climatic developments (Christensen et al., 2007; Kotir, 2011) and periodic variability (Tyson et al., 1975) were considered and a variety of future scenarios created. A disadvantage is that due to the resampling procedure, the range of extremes is constrained. However, a sufficiently long period of river flow records was available (1943-2011) and several extremes (both wet and dry) occurred in this period. For future precipitation, temperature and evapotranspiration data, the dataset CRU TYN (Mitchell et al., 2004) was used, but the resampling followed the same approach in order to reproduce the cyclic pattern.

For socioeconomic development, four scenarios were considered, following a rather pragmatic approach. Development rates within the study area were implemented directly in WEAP as percentages of growth rates (i.e. population, livestock, irrigation) obtained by literature review (BGR, 2005; DWA, 2005, 2008; Euroconsult, 2007; World Bank, 2010). In addition, an assumption was made that due to socioeconomic development (e.g. building of dams, abstractions for irrigation), the river flow entering the catchment from upstream might decrease by $10 \%$. This assumption is simple, but generally in agreement with predictions on future river flows and related studies (e.g. Goulden et al., 2009; World Bank, 2010; Beck \& Bernauer, 2011). Altogether, 40 scenarios were created (4 socioeconomic runs, each one under 10 climatic scenarios). We summarize the assumptions made and growth rates used for the creation of the scenarios in Appendix 3. For the present investigation on environmental flow assessment, two of the future scenarios were chosen:

i) Scenario I (SC-I), considering climatic changes in the form of increased variability of extreme events and cyclic climate variation, as well as assumed socioeconomic impacts in the form of a mean decrease of runoff by $10 \%$. According to the climate change reports (e.g. IPCC, 2007) and recent research (e.g. Goulden et al., 2009, Beck \& Bernauer, 2011), most of which agree that the variability of runoff will increase. This Scenario I represents a very likely situation under these conditions.

ii) Scenario II (SC-II), worst-case scenario: decrease of runoff by a mean of $10 \%$ due to socioeconomic reasons (i.e. increased water demand through population growth), and the occurrence of two dry periods following each other. This case was selected to investigate the feasibility of the current EFCs in a worst-case scenario.

\section{Assessment of forecasted hydrological change (monthly time scale)}

The hydrological indices of the flow regime, on a monthly basis, were used to compare current flow regime (EC, no relevant regulation) with the two selected future scenarios. Eleven 
hydrological indices, which are relevant for the river ecosystem (Olden and Poff 2003; Mathews and Richter 2007; Monk et al., 2006) were estimated from the monthly flow records (same time scale used in WEAP). The selected indices were a sub-set of those used in previous studies (Belmar et al., 2011; Garófano-Gómez et al., 2013) to characterize river flow. The main advantage of these indices is that they avoid redundancy and describe average conditions, interannual variability, inter-monthly variability, high flows and low flows.

\section{Assessment of critical habitats and relation with river flow}

The mulapos were considered as critical habitats because of their major relevance in the floodplains. The persistence of these habitats depends on their periodical inundation; thus the inundated area of mulapos (maximum in April) was considered as an indirect indicator of the ES "fish production". The total volume of water retained in the mulapos (not in the channel) at peak flow is related to the amount of water potentially recharging the aquifer, thus providing base flow during the dry season; therefore, it was considered as an indirect indicator of another ES, "regulation (and mitigation) of river flows".

These indicators were assessed using images of Landsat-7 (georeferenced Landsatlook images), provided by the USGS. First, the mapping of the mulapos was performed in a GIS using an image from May 2008 (a very wet year). May corresponds to the end of the wet season; rains have stopped and the remaining water indicated the extension of the mulapos. The Modified Normalized Difference Water Index (NMDWI) was used for this purpose. Based on this map the inundated area of mulapos was estimated for the month of highest flow (i.e. April) from 2001 to 2011. Then, a regression analysis between several indicators (i.e. mean wet season flow, maximum flow at the day of the satellite image) and inundated area of the mulapos was performed. The volume of water stored was estimated using the digital elevation model.

\section{Area-Duration Curves and Estimated Annual Habitat for the critical habitats}

The quantification of floodplain habitat for the three situations (EC versus scenarios) involved the analysis of hydrological time series of monthly river flow. We adapted the general approach by Matella \& Jagt (2013), using two indicators. First, the Area-Duration curve (AD curve) indicates the exceedance probability for the potential area of mulapos in the corresponding time series. This curve is equivalent to the habitat duration curves produced in the Alternative Analysis within the IFIM methodology (Bovee et al., 1998). Peak flows under EC and the two scenarios were fitted to a Log Pearson Type-3 (LPIII) distribution in HEC-SSP (USACE, 2010), to generate $95 \%$ and $5 \%$ confidence intervals around the probability distribution; the flowduration curves and confidence intervals were obtained in HEC-SSP. This analysis used the maximum flow before the day of each satellite image in the wet season, i.e. from January to June. The AD curves were calculated by transforming the flow-duration curves into areaduration curves, based on the aforementioned flow-area regression.

Secondly, the area under the AD curve, namely estimated annual habitat (EAH), predicts the likelihood of inundated areas of mulapos occurring in any given year. This indicator proposed by Matella \& Jagt (2013) was considered analogous to expected annual damages (EAD) used in flood risk analysis (Pingel and Ford, 2004). As this indicator integrates all the events, including the extremes, it is equivalent to an average over the whole period. Thus other complementary indicators were estimated on the $\mathrm{AD}$ curve based on the indices proposed for habitat time series analysis of the IFIM (Milhous et al., 1990). In this study we selected; i) A trimmed mean to represent the central habitat values (as the average of habitat area 
corresponding to the probability of exceedance $20 \%, 50 \%$ and $80 \%$ ); Index- $\mathrm{H}$ as indicator of the high habitat values (average of the habitat values between 0-10\% of exceedance probability); and ii) Index-L as indicator of the low habitat values (average of the habitat values between $90-100 \%$ of exceedance probability).

\section{General framework for the EFR}

Considering the conceptual framework of flow-biota relationships, the EFCs and the flowhabitat assessment, general guidelines for EFRs were proposed, intended to provide the basis for interim EFRs for normal years. This estimate could be used by water managers as a basic proposal, which could be incorporated into discussions for a public participation process, and the subsequent implementation and monitoring of the achieved solution, in the framework of an adaptive management of water resources. For the generation of such a proposal, the percentiles $\mathrm{P} 25^{\text {th }}$ and $\mathrm{P} 75^{\text {th }}$ of the EFC were considered; thus the range $\mathrm{P} 25^{\text {th }}-\mathrm{P} 75^{\text {th }}$ cover the situation of normal years, i.e. the central $50 \%$ of the data distribution in the time series. Thus, in $50 \%$ of the years, all the EFCs should be within the interquartile range defined here; in dry and wet years, lower and higher values than this general proposal should be ensured, respectively. The general aim of the EFR would be to maintain the EFCs in the range assessed in the existing condition; these are the initial flow management targets, according to the basic principles of the method of the RVA (Richter et al., 1997).

\section{RESULTS}

\section{Assessment of EFCs under Existing Condition}

For the calibration of the EFC algorithm, the standard two-step process was applied, with the "advanced calibration parameters" in the IHA software. Flows below $325 \mathrm{~m}^{3} \mathrm{~s}^{-1}$ were classified as low flows. For the separation of high flows into high-flow pulses, small floods, and large floods, small floods were defined as hydrological events with peak flows greater than $1350 \mathrm{~m}^{3} \mathrm{~s}^{-}$ ${ }^{1}$ (World Bank, 2010), and large floods were defined as those corresponding to peak flows of 15 years of return interval or more. The extreme low flows were assigned to low flows below the $5 \%$ percentile of the daily flows. With the same calibration settings, the high-flow pulses were assessed during the late dry season when the recession of high floods is finished (OctoberDecember), and in the wet season from the start to the maximum peak flow (January-April), because of the relation between high flows and fish migration during these periods.

The EFCs obtained from the mean daily flows (medians and coefficient of dispersion, respectively) and the different links between the EFCs and the fish community are shown in Table 1; the definition of the EFCs in the time series of river flow is illustrated in Fig. 3. These links are based on the conceptual framework provided for the Caprivi wetlands (previous section) and existing literature on the ecological relevance of the EFR (Richter et al., 2006; Mathews \& Richter, 2007; The Nature Conservancy, 2009). The trend assessment indicated some relevant results for the EFCs; specifically, four parameters showed negative trends over time, i.e. January Low Flow $\left(p<0.05 ; R^{2}=0.86\right)$, September Low Flow $\left(p<0.01 ; R^{2}=0.63\right)$, High Flow Timing $\left(p<0.05 ; R^{2}=0.68\right)$, and High Flow Fall Rate $\left(p<0.05 ; R^{2}=0.70\right)$. The median monthly flow showed significant negative trends in all the months, but the $\mathrm{R}^{2}$ were low; in August and September the $\mathrm{R}^{2}$ was approximately 0.51 .

Fig. 3 


\section{Future scenarios}

The stochastic generation of future scenarios aimed at incorporating two crucial aspects; an approximate 18-year climate cycle (Tyson et al., 1975) revealed by statistical analysis, and an increase of extreme events (both wet and dry) in the future (Christensen et al., 2007). The basic comparison of the scenarios and the observed time series are shown in Fig. 4, as well as the hydrographs of mean monthly flow for the observed time series and the two scenarios. In both scenarios a decrease in runoff can be observed. In the worst-case (SC-II) mean flow was reduced by ca. $20 \%$, which is significant. However, the $25^{\text {th }}$ and $75^{\text {th }}$ percentile remained very similar. Another relevant effect is shown in the extreme flows; the maximum flow reduced (highest whiskers) and the minimum flows increased. Regarding the monthly distribution of river flow, the future shape of the annual hydrographs mainly resembled the natural one. In SCI, however, mean high flows are slightly higher than in the observed series (more extremes). In both scenarios, peak flows appear to be more concentrated in April rather than distributed over April and May, as in the observed series. A decrease of runoff during the dry season can be identified when comparing the mean low flows (MNQ) of the three series; MNQ equals 270 $\mathrm{m}^{3} / \mathrm{s}$ for the observed series. For SC-I $\left(245 \mathrm{~m}^{3} / \mathrm{s}\right)$ and SC-II $\left(216 \mathrm{~m}^{3} / \mathrm{s}\right)$ these are notably lower.

Fig. 4

Mean rainfall decreased from $646 \mathrm{~mm}$ (observed) to $553 \mathrm{~mm}$ in SC-I. This is in good agreement with values provided by the climate models HADCM3 and CSIRO (IPCC, 2007). Precipitation in the worst-case scenario decreased by ca. $20 \%$ to a mean of $521 \mathrm{~mm}$. Mean temperature for the two scenarios increased by slightly more than $1{ }^{\circ} \mathrm{C}$ between 2012 and 2051 . Reference evapotranspiration increased by ca. $100 \mathrm{~mm} / \mathrm{y}$ to an approximated value of $1500 \mathrm{~mm} / \mathrm{y}$.

\section{Assessment of forecasted hydrological change}

The assessment of future hydrological changes indicated a remarkable mitigation of the flow variability. The reduction in the annual maximum flow and mean maximum flows (Fig. 4, Table 3 ) produce the reduction of the overall range of flows and the range (maximum minus minimum monthly flow). The hydrological indices representing average-flow indicate a small reduction under SC-I, but a dramatic reduction in SC-II, around 33\%, in terms of mean and median annual flow. These changes in magnitude, as well as the reduction of inter-annual variability (range) can be related with the relevant reduction in the maximum monthly flows -MH13 (-28\%); on the contrary, the reduction of minimum monthly flows is very small -ML13 (around $-10 \%$ in SC-II). The reduction of magnitude and increase in the dispersion of mean annual flow produce an increase in CVinter in SC-I; however, in SC-II the important reduction in the high flows and range makes the increase in CVinter irrelevant $(<6 \%)$.

\section{Table 3}

This effect is especially dramatic in SC-II, with reduction of $30 \%$ in range. The worst scenario is also highly affected by the total reduction of water yield, signifying an approximately $34 \%$ lower median annual flow. Such a reduction produces relevant effects in other indices, such as IL and AMIN/Q50; the latter indicates a reduction in the differences between medium and dry conditions, and its increase is $29 \%$ more than the EC.

Regardless of the reduction in maximum flows, the variability of maximum monthly flows $(\mathrm{CVH})$ and minimum monthly flows (CVL) remain very stable (any variation being smaller than 6\%). Although the mean of minimum monthly flows (ML13) barely decreases, in SC-II 
the reduction of mean and median flow, together with an increase of the Q95 of the monthly flows produce a clear increment in the drought intensity, IL. The minimum monthly flow suffers a reduction of $7 \%$ (AMIN; $394.80 \mathrm{~m}^{3} \mathrm{~s}^{-1}$ in 2042-43 versus $426.19 \mathrm{~m}^{3} \mathrm{~s}^{-1}$ in 1948-49), corroborating more severe conditions during the dry season in SC-II, although this effect is not observed in the AMIN/Q50.

\section{Assessment of critical habitats and relation with river flow}

The critical habitats - the mulapos - were shown in the GIS analysis (see Appendix 4), as they are the lowest areas in the floodplain that still remain inundated in the month of May. The peak flow $\left(\mathrm{m}^{3} \mathrm{~s}^{-1}\right)$ before the satellite image (April each year), with the corresponding area of mulapos $\left(\mathrm{km}^{2}\right)$ and volume of water in the floodplain $\left(\mathrm{km}^{3}\right)$, from 2001 to 2011, are shown in table 4 . The correlation between the maximum annual flow and the mulapos areas showed a good performance, with $\mathrm{R}^{2}=0.71$, as well as an ample range of $1553.9-6364.9 \mathrm{~m}^{3} \mathrm{~s}^{-1}$.

\section{Table 4}

\section{Area-Duration Curves and Estimated Annual Habitat}

The AD curves for the scenarios are shown in Figure 5. In the comparison between the existing conditions and SC-I (Fig. 5, upper plot), the main differences occur for events with the probability of exceedance equal to or greater than $51 \%$, i.e. related with some areas inundated with low and medium flows. In other types of events, the differences in probability are not significant, because there is an overlap between the confidence interval of both AD curves. In contrast, looking at the plot of SC-II (Fig. 5, lower plot), the differences are remarkable in the long term, affecting all the events with a probability of exceedance equal to or greater than $23 \%$. Accordingly, the AD curve indicators (Table 5) show a significant reduction under both EAH scenarios. Index-L (which indicates the area corresponding with the highest flows) decreased between 34 and $37 \%$ (with a slight difference between the two scenarios). The trimmed mean experienced a smaller reduction, between $17 \%$ and $25 \%$. However, the events with the highest probability of exceedance (lowest flows) do not inundate the floodplain, as they do not exceed the threshold value of $1350 \mathrm{~m}^{3} \mathrm{~s}^{-1}$. Therefore, the most relevant changes are those in relation with the trimmed mean and the index-H.

Fig. 5

\section{Table 5}

\section{General framework for the EFR}

Based on the conceptual framework of flow-biota relationships, the EFCs and the habitat analyses performed, this general framework for the EFR was elaborated:

- Mean monthly flows during the dry season (June-December). During the dry season, the EFCs of Low Flows correspond to the base flows in the following intervals (P25 $\left.5^{\text {th }}-\mathrm{P} 75^{\text {th }}\right)$ per month; 347.9-374.9 $\mathrm{m}^{3} \mathrm{~s}^{-1}$ (June), 296.5-345 $\mathrm{m}^{3} \mathrm{~s}^{-1}$ (July), 286.9-345.1 $\mathrm{m}^{3} \mathrm{~s}^{-1}$ (August), 265.2-313.6 m $\mathrm{m}^{3} \mathrm{~s}^{-1}$ (September), 266.1-312.5 m $\mathrm{m}^{3} \mathrm{~s}^{-1}$ (October), 277.2-310.9 $\mathrm{m}^{3} \mathrm{~s}^{-1}$ (November), 275.6-322 $\mathrm{m}^{3} \mathrm{~s}^{-1}$ (December).

- High-flow pulses during the dry season. Although the increase of flow should occur as a result of the gradual increase of flow in natural conditions, in the case of regulation, such a 
change could be dampened due to specific dam operation rules for water management. Therefore in this case, the high-flow pulses are necessary in the late dry period, due to their ecological relevance; for instance, based on the 7-day maximum flow, one of the EFCs could be within the range of $346-619 \mathrm{~m}^{3} \mathrm{~s}^{-1}$, over 7 consecutive days (data not shown).

- Mean monthly flows during the wet season (January-May). During this season the mean monthly flows gradually increase until reaching their maximum (typically in April) and decrease in May. The central intervals $\left(\mathrm{P} 25^{\text {th }}-\mathrm{P} 75^{\text {th }}\right)$ of these mean monthly flows correspond to; 475.7-837.7 $\mathrm{m}^{3} \mathrm{~s}^{-1}$ (January), 769.9-1360 $\mathrm{m}^{3} \mathrm{~s}^{-1}$ (February), 1064-3338 $\mathrm{m}^{3} \mathrm{~s}^{-}$ ${ }^{1}$ (March), 2221-3858 $\mathrm{m}^{3} \mathrm{~s}^{-1}$ (April), 1627-3070 $\mathrm{m}^{3} \mathrm{~s}^{-1}$ (May). These flow rates involve flooding during a continuous period every year $\left(\mathrm{Q}>1350 \mathrm{~m}^{3} \mathrm{~s}^{-1}\right)$, as indicated in the analysis of the EFC, named as Small Floods (frequency =1). These events involve the targets of Rise Rate (16.64-34.66 $\left.\mathrm{m}^{3} \mathrm{~s}^{-1} \mathrm{day}^{-1}\right)$ and Fall Rate (-26.21-16.84 $\left.\mathrm{m}^{3} \mathrm{~s}^{-1} \mathrm{day}^{-1}\right)$.

- Peak flow of Small Floods. These floods, which partially cover the floodplain occur almost every year; as stated above, the increase of flow until peak flow is gradual. Maximum peak flow during the Small Floods, occurring within the time window from the start to the end of April (Julian day from 92 to 117) showed a median of $3498 \mathrm{~m}^{3} \mathrm{~s}^{-1}$ and an interval of $2507-4386 \mathrm{~m}^{3} \mathrm{~s}^{-1}$. This is considered as the largest target-flow pulse in a regular year; thus, assuming a gradual increase of flows during the wet season, it was not considered necessary to define additional flow pulses. In the case that decisions in water management produce a damping of the flow increase, a high-flow pulse of 2507-4386 $\mathrm{m}^{3} \mathrm{~s}^{-1}$ would be necessary during April.

- Large Floods. These floods (with recurrence interval of 15 years) produce the peak flow in April (Julian day from 100 to 114). The target interval of the flood peak is $6251-6817 \mathrm{~m}^{3} \mathrm{~s}^{-}$ 1. As well as the small (regular) floods, these occur after a gradual increment of flow and water level during the wet season.

\section{DISCUSSION}

The characterisation of the hydrological parameters named Environmental Flow Components (Matthews and Richter, 2007) has provided a holistic description of the actual hydrological conditions as a fundamental baseline for future hydrological comparisons and environmental flow assessments. In the future, the environmental impact study of a hydraulic infrastructure, or the licensing process of a water abstraction, can be supported by the analysis of hydrological alteration (Richter et al., 1996) if there is a hydrological model to forecast daily river flows. Therefore, the pre-impact flow records - described herein - can be compared with post-impact flow records to determine which EFCs have been altered and in what manner or degree (Matthews and Richter, 2007). Likewise, different future scenarios could be evaluated, such as the construction of a hydropower plant with specific operation rules, socioeconomic development or changes in land use.

Furthermore, our new conceptual framework of flow-ecology relationships allows the formulation of hypotheses about the future potential impacts of a given future scenario on some ecological processes and on fish populations. Thus, this piece of research establishes a starting point to explore the relationships between a variety of ecological processes and the flow regime, similar to previous studies in equatorial rivers (McClain et al., 2014). In this study, given the 
limitation of data, our conceptual model focuses on fish populations and directly related processes, while some studies on EFRs with holistic approaches have formulated conceptual models and hypotheses about fish and riparian vegetation (Dickens, 2011; McClain et al., 2014). Here we corroborate that the EFCs and their variability may become the building blocks of flow-ecology models that lead to environmental flow recommendations, monitoring and research programs, and flow restoration and protection activities (Matthews and Richter, 2007).

Certainly, these EFCs in the form of intervals $\left(\mathrm{P} 25^{\text {th }}-\mathrm{P} 75^{\text {th }}\right)$ are useful as a baseline for the future definition of EFRs, but the definition of minimum thresholds could be an interesting step, which was beyond the scope of this study. Some of the simplest hydrological methods for EFAs only define a fixed percentage of the mean annual flow, often termed the minimum flow (Tharme, 2003). Other hydrological methods consider the natural variability, from the simple Presumptive Standards (Richter et al., 2012) to other, more complex, techniques like the Base Flow Method (Palau and Alcazar, 1996) or the Desktop Method (Hughes and Hannart, 2003), where the former was feasible here due to its data requirements. The Presumptive Standards method (Richter et al., 2012) suggests the restriction of the hydrologic alterations to within a percentage-based range around natural or historic flow variability, which was initially established at a maximum of $\pm 10 \%$ of the mean monthly flow (in the case of a high level of ecological protection) or $\pm 20 \%$ (in the case of moderate ecological protection). However, in the Zambezi River the hydrological variability of mean monthly flows naturally exceeds these presumptive percentages of deviation; e.g. in March and April the percentile P75\% was $41 \%$ and $27 \%$ higher than the median monthly flow, respectively. Thus the target intervals of the RVA method, comprising the central $50 \%$ of the data distribution, are notably wider than the presumptive standards for the ecological protection.

Therefore, we decided to provide an orientation based on the interquartile range, where the median monthly flow should fit in 50\% of instances and should be lower in $25 \%$ of instances, based on the natural flow regime. The RVA is a suitable orientation for rivers with ample hydrological records, instead of the Presumptive Standards, which were specifically created for study sites with data scarcity. The monthly time scale can be considered adequate in this context, because many water planners continue to use hydrologic models that operate on a monthly time step (Richter et al., 2012), and there is no intra-daily regulation here. Additionally, the RVA goes further in the assessment of flow quantity, quality, timing, and duration of the river flows, which are critical for ecosystem integrity in regions like Caprivi, where flooding is needed to maintain fish habitats and permit the fish migration.

At the time scale of the last 35 years, the trend analysis of the IHA software indicated that the EFCs have been changing in some aspects. The low flow in September and January has decreased. These trends could be due to a variety of reasons, such as progressive reduction of precipitation, changes in temperature, gradual changes in land use and hydrology (e.g. proportion of forested versus agricultural land cover), or abrupt changes, such as new irrigation schemes, or a gradual increment of water abstractions with increasing population in the basin. The negative trend in the median monthly flows was general, although only robust in August and September. Therefore, the slow reduction in the water yield in every month, and the consequent reduction in the recharge of the alluvial aquifer during the wet season, makes the hypotheses of a natural alteration plausible. However, a more intensive use of water resources during the dry season could be also relevant. Such analysis would require more information and analyses, which are beyond the scope of this study. The high flow timing and fall rate also decreased, but these events were very scarce in the time series $(\mathrm{N}=3)$, thus the trend was not considered representative. 
The reasons for the decline in low flows during the last 35 years are relevant when discussing the future feasibility of EFRs, because such a reduction could affect the applicability of environmental flows based solely on hydrological methods. September and October are the months with the smallest median monthly flows (Table 1) and the lowest percentile 25th corresponds to September. Therefore, the decreasing trend during September may negatively affect connectivity, and thus the dispersion and migrations of several species, the spawning of quiet-water species and the survival of fish during this limiting period. In the last decade of analysis, the Extreme Low Flows also occurred in some days of August, November and December. Although the trend of Low Flow in September was significant, the positive trends in Extreme Low Duration and Extreme Low Frequency only presented weak correlations. Furthermore, in SC-II the increase of the drought intensity and the number of days with Extreme Low Flows is notable (Table 3, Fig. 5), which may affect particularly in September and October. Therefore, the probability of the aforementioned severe ecological effects is considered to be very high.

Notably, the scenarios created compare well to those obtained by studies using more complex approaches, such as water balance modelling. Beck and Bernauer (2011), for instance, created a hydrological model of the whole Zambezi river basin and investigated a variety of climatic and socioeconomic scenarios and their impact on river flow in the Zambezi. The results of SCII $\left(Q_{\text {mean }}\right.$ at Victoria Falls of $\left.747 \mathrm{~m}^{3} / \mathrm{s}\right)$ matches well with scenario (2) $\left(\mathrm{Q}_{\text {mean }}\right.$ at Victoria Falls of $720 \mathrm{~m}^{3} / \mathrm{s}$ ) from Beck and Bernauer (2010). In this scenario the authors assumed "moderate demand and supply side changes and moderate climatic changes". In SC-I presented here produced a $Q_{\text {mean }}$ of $899 \mathrm{~m}^{3} / \mathrm{s}$, which is between the two scenarios (1) ( $Q_{\text {mean }}$ at Victoria Falls of $1002 \mathrm{~m}^{3} / \mathrm{s}$ ) and (2) studied by Beck and Bernauer (2011). Whilst the focus of the cited study is more on socioeconomic development (in particular irrigation expansion), our procedure prefers climatic developments since the socioeconomic part can be easily extended within the WEAP model. Even though the approach of Beck \& Bernauer (2010) is more holistic, comprising a larger scale and all possible influencing factors, a pragmatic approach, such as that applied here, might be more practicable; we focused on one catchment and investigated how this catchment would be affected if the inflow decreased. By analysing the long time series, cyclic patterns were identified and included into future scenario creation. This is an advantage compared to the current climate models, which do not adequately take into account such factors (Tadross et al., 2007). Often, there is neither a sufficient climate network with reliable and spatially dense network of historical records, nor is the effect of climatic and socioeconomic changes on the huge wetlands (i.e. Barotse) accurately predictable. By using the relatively long time-series of Katima Mulilo and analysing the effect of certain observed extreme years on the Caprivi-Chobe wetland and runoff downstream, future developments might be assessed as realistic as in more complex approaches.

The future hydrological changes indicated a remarkable mitigation of the flow variability, especially dramatic in SC-II, where the total reduction of water yield comprised approximately $34 \%$ smaller median annual flows. In accordance with the smaller flows, the AD curves indicate that the area inundated, for a given frequency, will be smaller in general. In SC-I, the impact is relevant, because approximately $49 \%$ of the events result in a significant reduction of the inundated area of mulapos. Under SC-II the impact is remarkable, because the events with probability of exceedance larger than $23 \%$ will be altered. Therefore, the area of mulapos would be reduced in the long term, with consequent physical and ecological changes, especially in the highest areas above the elevation of the river channel. From a hydrological perspective, the reduction in peak flows and habitat inundation mean a reduction of the recharge in the alluvial 
aquifer during the wet season and lower base flow during the dry season. The relation between these processes is not linear and specific studies would be necessary to estimate such effects.

Accordingly, and based on our conceptual model, we hypothesize that the reduction in the areas of mulapos would produce a reduction of the habitats for the spawning of quiet-water species, the food resources available for the fry and juvenile fish, and finally a reduction of the fish stocks. Some fish species that are more sensitive to the flow reduction would be more affected in terms of mortality during the dry season, as it is known that generally there is a high natural mortality of fish in the isolated pools and streams (Purvis, 2002) after the recession of the high floods. The total loss of habitat, in the long term, was estimated to be $14 \%$ and $22 \%$ (Table 5), for SC-I and SC-II, respectively. Furthermore, the habitat loss during low events is similar and greater under both scenarios, at around 35\%. As a consequence, we hypothesize that there could be a relevant reduction in the ecosystem services (ES) related, that is, to the fisheries associated to the dry season and in the extensive fish farming occurring in some mulapos. A limitation of these results can rely on the extrapolation of the correlation between peak flow and area. In the two scenarios the highest peak flows (5695 and $4553 \mathrm{~m}^{3} \mathrm{~s}^{-1}$ for SC-I and SC-II, respectively) are within the range of the correlation, but the lowest peak flows $\left(790 \mathrm{~m}^{3} \mathrm{~s}^{-1}\right)$ are lower than those in the natural condition, which may be considered a limitation of this assessment.

From the climatic and hydrological perspective, the stochastically created future scenarios have shown a decrease in the mean monthly flows in both scenarios as it was expected. Under SC-I, with increased variability of extreme events and cyclic climate variation, as well as a mean decrease in runoff by $10 \%$, the median annual flow remained very similar (a reduction of $2.4 \%$ ) as well as the quartiles. However, this reduction turns out to be very significant for SC-II, considering a decrease in runoff by a mean of $10 \%$ and the occurrence of two consecutive dry periods. The WEAP model can be regarded as a link between hydrology and socio-economy and, once parameterized it provides great opportunities to study scenarios. Socioeconomic predictions can be easily implemented into the model as well as economic analysis. This makes the model a very valuable tool for impact studies. A crucial aspect, however, is that a variety of reasonable climatic pathways is developed in a previous step. Stochastic procedures such as those applied in the present research might be an alternative to the use of climate predictions provided by global or regional circulation models. Stream flow is a hydrological variable that can be measured with a higher accuracy than rainfall. It further contains information on the whole catchment (or sub-catchment, depending on the station density). Using this information as a baseline for future assessments might be beneficial, especially in areas where other data are scarce. The results show how different development paths for climate and socio-economy affect water resources and provide an opportunity to investigate, define and implement adaptation strategies to mitigate impacts. Furthermore, in the future situation of a greater data availability, it would be possible to use more integrative approaches of water resources management, considering habitat analysis (physical habitat models) and hydrological information in the assessment of EFRs (Paredes et al., 2014).

After the incorporation of habitat analysis and a conceptual ecological framework, this study demonstrates the importance of integrating different approaches in e-flows and also of considering the impact of climate change on environmental flows, as recent studies also demonstrated (Thompson et al., 2014). The river and its floodplain should be considered as one unit with regards to the water, sediments and organic budgets (river-floodplain system). The results show the suitability of the habitat duration curves to analyse the effects of the flow regulation and the climate change on the floodplain habitats, as suggested by Matella and Jagt (2013). 
The complex and diverse floodplain ecosystems provide important habitats for the biota and fundamental ecological services for the populations, whose resources are intimately related to the annual flood pulse, with specific characteristics of magnitude, timing, duration, rise and fall rate. From the socioeconomic perspective, the populations in the floodplains are dependent on the variability of river flows and will be influenced by the implementation of EFRs under scenarios of further development. The outcomes of this research are undoubtedly motivating for further research on environmental flows, ecosystem services and sustainable water resources management in the Eastern Caprivi.

One of the relevant future steps, in the refinement of EFRs, can be the interpretation of the hydrological parameters shown here in the light of the river hydraulics. For example, McClain et al. (2014) quantified some of the EFCs in the Mara River, converted them into hydraulic variables and presented the ecological interpretation of the environmental flows for macroinvertebrates, fish and riparian vegetation in specific study sites. Accordingly, in different frameworks for environmental flows such as IFIM (Bovee et al., 1998) and in holistic methodologies like the BBM and the DRIFT, the interpretation of hydrological information with hydraulic models is fundamental to understanding flow-ecology relationships (Arthington et al., 2003; King \& Brown, 2007); in the BBM, the hydraulic information is of quintessential importance to the success of the process as a whole (King et al., 2008).

In the Caprivi Region, as in other rivers with a low level of abstraction or regulation, water managers are advised to pay special attention to the low-flow or extreme low-flow parameters in the EFR (Mathews \& Richter, 2007) and take action when water abstractions may jeopardize multiple ES provided by the rivers. The availability of ES in the future is dependent on climate, management practices and socio-economy.

The hydrological characterisation of the flow regime, both at the daily and monthly time scale, has provided a baseline to develop a first conceptual framework of flow-ecology linkages in this region, based on existing literature. One of the limitations of this study is that there was no acquisition of experimental data or a plan for monitoring the characteristics of the fish communities. Nevertheless, the conceptual model presented here could be the first step for proposing hypotheses about the ecological processes, proposing monitoring activities to test new hypotheses, and finally applying an iterative process, which should result in the refining of EFRs, in the framework of an adaptive management process (Matthew and Richter, 2007).

\section{ACKNOWLEDGMENTS}

This research was part of the research project CERPA (Certification of Protected Areas), funded by the German Federal Ministry of Education and Research (BMBF), and focused on the evaluation of new market-based instruments for biodiversity conservation and their socioeconomic implications. The authors also thank two anonymous reviewers who provided substantial input that improved the manuscript. The study has been partially funded by the national Research project IMPADAPT (CGL2013-48424-C2-1-R), with MINECO (Spanish Ministry of Economy) and FEDER funds.

\section{REFERENCES}

Arthington AH. 1998. Comparative Evaluation of Environmental Flow Assessment Techniques: Review of Holistic Methodologies. Occasional Paper No. 26/98. Land and Water Resources Research and Development Corporation: Canberra. 
Arthington AH, Rall JL, Kennard MJ, Pusey BJ. 2003. Environmental flow requirements of fish in Lesotho Rivers using the DRIFT methodology. River Research and Applications 19: 641-666.

Barnard P. 1998. Biological diversity in Namibia: a country study. Namibian National Biodiversity Task Force: Windhoek.

Beck L, Bernauer T. 2011. How will combined changes in water demand and climate affect water availability in the Zambezi river basin? Global Environmental Change 21: 10611072. DOI: 10.1016/j.gloenvcha.2011.04.001

Belmar O, Martínez-Capel F, Velasco J. 2011. Hydrological Classification of natural Flow Regimes to Support Environmental Flow Assessments in Intensively Regulated Mediterranean Rivers, Segura River Basin. Environmental Management 47: 992-1004.

Beyer M, Billib M. 2013. Certification of Protected Areas (CERPA) - an evaluation of international markets and their socioeconomics implications using the examples of wetlands in sub-Saharan Africa. Results from the working package "Hydrology and water Resources" (unpublished). Available online; http://www.the-eis.com/data/literature/ Cerpa_Hydrology_Final_Report_MB.pdf

BGR. 2005. Groundwater Investigations in the Eastern Caprivi Region: Main Hydrogeological Report. Federal Institute for Geosciences and Natural Resources (BGR): Hannover.

Bovee KD, Lamb BL, Bartholow JM, Stalnaker CB, Taylor J, Henriksen J. 1998. Stream habitat analysis using the instream flow incremental methodology. US Geological Survey, BRD Information and Technology Report USGS/BRD-1998-0004.

Bragg OM, Black AR, Duck RW. 1999. Anthropogenic Impacts on the Hydrology of Rivers and Lochs. Literature Review and Proposed Methods. Revised Stage 1 Report No. W98(50) I1. Geography Department, University of Dundee: Dundee.

Brauman KA, Daily GC, Duarte TK, Mooney HA. 2007. The nature and value of ecosystem services: an overview highlighting hydrological services. Annual Review of Environment and Resources 32: 67-98. DOI:10.1146/annurev.energy.32.031306.102758.

Capon T, Parsons M, Thoms M. 2009. Floodplain ecosystems: resilience, value of ecosystem services and principles for diverting water from floodplains. Waterlines report, National Water Commission: Canberra.

Carpenter SR, Mooney HA, Agard J, Capistrano D, DeFries RS, Díaz S, Dietz T. 2009. Science for managing ecosystem services: Beyond the Millennium Ecosystem Assessment. Proceedings of the National Academy of Sciences 106: 1305-1312. DOI: 10.1073/pnas.0808772106

Christensen JH., Hewitson B, Busuioc A, Chen A, Gao X, Held I, Jones R, Kolli RK, Kwon WT, Laprise R, Magaña Rueda V, Mearns L, Menéndez CG, Räisänen J, Rinke A, Sarr A, Whetton P. 2007. Regional Climate Projections. In Climate Change 2007: The Physical Science Basis. Contribution of Working Group I to the Fourth Assessment Report of the Intergovernmental Panel on Climate Change. Solomon S, Qin D, Manning M, Chen Z, 
Marquis M, Averyt KB, Tignor M, Miller HL (Eds.). Cambridge University Press: Cambridge.

Dickens, C. 2011. Critical analysis of environmental flow assessments of selected rivers in Tanzania and Kenya. IUCN ESARO: Nairobi and INR: Scottsville.

DWA, 2005. Summary of Water Accounts. Department of Water Affairs (DWA), Ministry of Agriculture, Water and Forestry: Windhoek.

DWA, 2008. Summary of Water Accounts. Department of Water Affairs (DWA), Ministry of Agriculture, Water and Forestry: Windhoek.

MacDonald, Euroconsult Mott. 2008. Integrated Water Resources Management Strategy and Implementation Plan for the Zambezi River Basin. Southern African Development Community Water Division/Zambezi River Authority (SADC-WD/ZRA): Lusaka.

Garófano-Gómez V, Martínez-Capel F, Bertoldi W, Gurnell A, Estornell J, Segura-Beltrán F. 2013. Six decades of changes in the riparian corridor of a Mediterranean river: a synthetic analysis based on historical data sources. Ecohydrology 6: 536-553. DOI: 10.1002/eco.1330.

Global Runoff Data Centre (GRDC). 2013. River Flow Data of the World. Global Runoff Data Centre. Federal Institute of Hydrology (BfG): Koblenz.

Goulden M, Persechino A, Conway D. 2009. Adaptation to climate change in international river basins in Africa: A review. Hydrological Sciences Journal 54: 805-828.

Grunewald K, Bastian O. 2012. Ökosystemdienstleistungen: Konzept, Methoden und Fallbeispiele. Leibniz Institute of Ecological Urban and Regional Development (IOER). Springer: Berlin. DOI: 10.1007/978-3-8274-2987-2.

Harris I, Jones PD, Osborn TJ, Lister DH. 2014. Updated high-resolution grids of monthly climatic observations - the CRU TS3.10 Dataset. International Journal of Climatology 34: 623-642. DOI:10.1002/joc.3711

Ikomi RB. 1996. Studies on the growth pattern, feeding habits and reproductive characteristics of the mormyrid Brienomyrus longianalis (Boulenger 1901) in the upper Warri River, Nigeria. Fisheries Research 26: 187-198.

IPCC. 2007. IPCC Fourth Assessment Report: Climate Change 2007. Intergovernmental Panel on Climate Change: Cambridge.

Junk WJ, Bayley PB, Sparks RE. 1989. The flood pulse concept in river-floodplain systems. Canadian Special Publication of Fisheries and Aquatic Sciences 106: 110-127.

King J, Brown C. 2006. Environmental flows: striking the balance between development and resource protection. Ecology and Society 11: 26.

King JM, Tharme RE, de Villiers MS (Eds.). 2008. Environmental flow assessments for rivers: manual for the Building Block Methodology. WRC Report TT 354/08. Water Research Commission: Pretoria. 
Kirschbaum F, Schugardt C. 2002. Reproductive strategies and developmental aspects in mormyrid and gymnotiform fishes. Journal of Physiology Paris 96: 557-566.

Kotir J. 2011. Climate change and variability in Sub-Saharan Africa: a review of current and future trends and impacts on agriculture and food security. Environment, Development and Sustainability 13: 587-605.

Kundzewicz ZW, Robson AJ. 2004. Change detection in hydrological records-a review of the methodology / Revue méthodologique de la détection de changements dans les chroniques hydrologiques. Hydrological Sciences Journal 49: 7-19. DOI:10.1623/hysj.49.1.7.53993.

Matella MK, Jagt K. 2013. An Integrative Method for Quantifying Floodplain Habitat. Journal of Water Resources Planning and Management 140(8): 06014003. DOI: 10.1061/(ASCE)WR.1943-5452.0000401.

Mathews R, Richter BD. 2007. Application of the indicators of hydrological alteration software in environmental flow setting. Journal of the American Water Resources Association 43: 1400-1413. DOI: 10.1111/j.1752-1688.2007.00099.x.

McClain ME, Subalusky AL, Anderson EP, Dessu SB, Melesse AM, Ndomba PM, Mtamba JOD, Tamatamah RA, Mligo C. 2014. Comparing flow regime, channel hydraulics, and biological communities to infer flow-ecology relationships in the Mara River of Kenya and Tanzania. Hydrological Sciences Journal 59: 801-819.

Mendelsohn, JM, Roberts C. 1997. An environmental profile and atlas of Caprivi. Gamsberg Macmillan: Windhoek.

Milhous RT, Bartholow JM, Updike MA, Moos AR. 1990. Reference manual for generation and analysis of habitat time series- Version II. Instream Flow Information paper $\mathrm{n}^{\circ} 27$. U.S. Fish \& Wildlife Service Biological Report 90-16.

Millenium Ecosystem Assessment, 2005. Ecosystems \& human well-being: synthesis. Millenium Ecosystem Assessment. Island Press: Washington, D.C.

Ministry of Fisheries and Marine Resources (MFMR). 1995. White Paper on the Responsible Management of the Inland Fisheries of Namibia. Ministry of Fisheries and Marine Resources: Windhoek.

Mitchell TD, Carter TR, Jones PD, Hulme M, New M. 2004. A comprehensive set of highresolution grids of monthly climate for Europe and the globe: the observed record (1901-2000) and 16 scenarios (2001-2100). Tyndall Working Paper 55. Tyndall Centre for Climate Change Research, University of East Anglia: Norwich.

Monk WA, Wood, PJ, Hannah, DM. Wilson DA, Extence CA, Chadd RP. 2006. Flow variability and macro invertebrate community response within riverine systems. River Research and Applications 22: 595-615.

Naiman RJ, Latterell JJ, Pettit NE, Olden JD. 2008. Flow variability and the biophysical vitality of river systems. Comptes Rendus Geoscience 340: 629-643. 
Nicholson E, Mace GM, Armsworth PR, Atkinson G, Buckle S, Clements T, Ewers RM. 2009. Priority research areas for ecosystem services in a changing world. Journal of Applied Ecology 46: 1139-1144. DOI: 10.1111/j.1365-2664.2009.01716.x

Olden JD, Poff NL. 2003. Redundancy and the choice of hydrological indices for characterizing stream flow regimes. River Research and Applications 19: 101-121.

Paredes-Arquiola J, Solera A, Martinez-Capel F, Momblanch A, Andreu J. 2014. Integrating water management, habitat modelling and water quality at the basin scale and environmental flow assessment: case study of the Tormes River, Spain. Hydrological Sciences Journal 59: 878-889.

Peel R, Tweddle D, Weyl OLF, Chinyawezi K, Kalauka R. 2013. Ecological and socioeconomic baseline assessment of artisanal fishing in the Greater Liuwa Ecosystem, Western Zambia. Report 5: Fisheries Survey. African Parks Zambia, Liuwa Plain National Park: Kalabo.

Pingel N, Ford D. 2004. Interior Floodplain Flood-Damage Reduction Study. Journal of Water Resources Planning and Management 130: 123-130.

Purvis J. 2002. Fish and livelihoods: Fisheries on the eastern floodplains, Caprivi (No. 52). Directorate of Environmental Affairs, Ministry of Environment and Tourism: Windhoek.

Richter B, Baumgartner J, Wigington R, Braun D. 1997. How much water does a river need? Freshwater biology 37: 231-249.

Richter BD, Warner AT, Meyer JL, Lutz K. 2006. A collaborative and adaptive process for developing environmental flow recommendations. River research and applications 22: 297-318. DOI: 10.1002/rra.892.

Richter BD, Baumgartner JV, Powell J, Braun DP. 1996. A method for assessing hydrological alteration within ecosystems. Conservation Biology 10: 1163-1174.

Richter BD, Davis MM, Apse C, Konrad C. 2012. A presumptive standard for environmental flow protection. River Research and Applications 28: 1312-1321.

Skelton P. 1993. A complete guide to the freshwater fishes of Southern Africa. Southern Book Publishers: Cape Town.

Souchon Y, Sabaton C, Deibel R, Reiser D, Kershner J, Gard M, Katopodis C, Leonard P, Poff NL, Miller WJ, Lamb BL. 2008. Detecting biological responses to flow management: missed opportunities; future directions. River Research and Applications 24: 506-518.

Sparks RE, Nelson JC, Yin Y. 1998. Naturalization of the flood regime in regulated rivers. BioSciences 48: 706-720.

Swenson SC. 2012. GRACE monthly land water mass grids NETCDF RELEASE 5.0. Ver. 5.0. PO.DAAC, CA, USA. Dataset accessed [2012-08-15]. DOI: 10.5067/TELND-NC005.

Tadross M, Suarez P, Lotsch A, Hachigonta S, Mdoka M, Unganai L, Kamdonyo D, Muchinda M. 2009. Changes in growing-season rainfall characteristics and downscaled scenarios of 
change over southern Africa: implications for growing maize. Climate Research 40: 147161.

Tharme RE. 2003. A global perspective on environmental flow assessment: Emerging trends in the development and application of environmental flow methodologies for rivers. River Research and Applications 19: 397-441.

The Nature Conservancy. 2009. Indicators of Hydrological Alteration Version 7.1 User's Manual. The Nature Conservancy: Arlington.

The World Bank, 2010. The Zambezi River Basin A Multi-Sector Investment Opportunities Analysis. Vol. I-IV. World Bank: Washington D.C.

Thompson JR, Laizé CLR, Green AJ, Acreman MC, Kingston DG. 2014. Climate change uncertainty in environmental flows for the Mekong River. Hydrological Sciences Journal 59: 935-954. DOI: 10.1080/02626667.2013.842074.

Thorstad EB, Clinton JH, Økland F, Nickandor N, Næsje TF. 2007. Spatial behaviour and management of greenhead tilapia (Oreochromis macrochir) in the Zambezi River, Namibia. NINA Rapport 287. Norsk Institutt for Naturforskning (NINA): Troms $\emptyset$.

Thorstad EB, Hay CJ, Næsje TF, Økland F. 2001. Movements and habitat utilization of three cichlid species in the Zambezi River, Namibia. Ecology of Freshwater Fish 10: 238-246.

Turpie J, Smith B, Emerton L, Barnes J. 1999. Economic value of the Zambezi Basin Wetlands. IUCN Regional Office for Southern Africa: Capetown.

Tvedten I. 1994. Freshwater fisheries and fish management in Namibia: A socioeconomic background study. Social Sciences Division, Multi-Disciplinary Research Center, University of Namibia: Windhoek.

Tyson PD, Dyer JTG, Mametse MN. 1975. Secular changes in South African rainfall: 1880 to 1975. Quarterly Journal of the Royal Meteorological Society 101: 817-833.

USACE - U.S. Army Corps of Engineers. 2010. HEC-SSP Statistical Software Package User's Manual, Version 2.0. Hydrological Engineering Center: Davis.

Van der Waal BCW, Skelton PH. 1984. Check list of fishes of the Caprivi. Madoqua 13: 303320.

Weyl OLF, Ribbink AJ, Tweddle D. 2010. Lake Malawi: fishes, fisheries, biodiversity, health and habitat. Aquatic Ecosystem Health \& Management 13: 241-254. 
Table 1. Environmental flow components (EFC; median, percentiles 25th and 75th) under the existing condition (period from 1965-66 to 1999-2011). Only values of months experiencing low flows are shown. For Extreme low flows, EFC include peak (minimum flow rate during the event, $\mathrm{m}^{3} \mathrm{~s}^{-1}$ ), duration (days), timing (Julian date of peak flow) and frequency (number of events per water year). The EFCs for high flows (pulses), small floods and large floods are the peak, duration, timing, frequency (same units), rise rate and fall rate $\left(\mathrm{m}^{3} \mathrm{~s}^{-1} \mathrm{day}^{-1}\right)$. The third column shows a summary of the influence of each group of EFC on fish communities in the Caprivi region.

$\begin{array}{llll}\text { Median } & \text { P25 } & \text { P75 } & \begin{array}{l}\text { Eco. processes linking flow regime } \\ \text { \& fish community in Caprivi }\end{array}\end{array}$

\section{$\underline{\text { EFC Low flows }}$}

October - Low Flow

November - Low Flow

December - Low Flow

January - Low Flow

June - Low Flow

July - Low Flow

August - Low Flow

September - Low Flow

\section{$\underline{\text { EFC Parameters }}$}

Extreme low peak

Extreme low duration

Extreme low timing

Extreme low freq.

High flow peak

High flow duration

High flow timing

High flow freq.

High flow rise rate

High flow fall rate

Small Flood peak

Small Flood duration

Small Flood timing

Small Flood freq.

Small Flood rise rate

Small Flood fall rate

Large flood peak

Large flood duration

Large flood timing

Large flood freq.

Large flood rise rate

Large flood fall rate

$\begin{array}{lll}286.2 & 266.1 & 312.5 \\ 296.6 & 277.2 & 310.9 \\ 306.3 & 275.6 & 322.0 \\ 304.9 & 293.7 & 326.3 \\ 354.1 & 347.9 & 374.9 \\ 332.5 & 296.5 & 345.0 \\ 309.0 & 286.9 & 345.1 \\ 290.3 & 265.2 & 313.6\end{array}$

- Enable fish to move to feeding and spawning areas in low-flow habitats

- spawning of fish species in slowflowing or standing waters or lagoons

- Provide adequate habitat space

- Keep fish eggs suspended 
Table 2. Required input data for the WEAP model of the Caprivi-Chobe floodplains, used datasets, methods and sources.

\begin{tabular}{|c|c|c|}
\hline Input variable & Dataset/ Method & Source/Reference \\
\hline Inflow to catchment & River flow at Katima Mulilo & DWA* \\
\hline Precipitation & CRU TS 3.1/ Model & Harris et al. (2014) \\
\hline Ref. evapotranspiration & CRU TS 3.1/ Model & Harris et al. (2014) \\
\hline Temperature & CRU TS 3.1/ Model & Harris et al. (2014) \\
\hline Groundwater recharge & GRACE/Own analysis & $\begin{array}{l}\text { Swenson (2012); Beyer \& } \\
\text { Billib (2013) }\end{array}$ \\
\hline Total flood volume & $\begin{array}{l}\text { River flow at Katima Mulilo/ } \\
\text { Peak-over-threshold }\end{array}$ & $\begin{array}{l}\text { DWA; Beyer \& Billib } \\
\text { (2013) }\end{array}$ \\
\hline Water demands & Various/ Growth rates & $\begin{array}{l}\text { World Bank (2010); DWA } \\
(2005,2008) ; \text { BGR (2005) }\end{array}$ \\
\hline Flow to Lake Liambezi & Landsat 7/ Own analysis & Beyer \& Billib (2013) \\
\hline Outflow of catchment & River flow at Victoria Falls & Zambezi River Authority \\
\hline
\end{tabular}


Table 3. Hydrological indices of the flow regime for comparison of two climatic and socioeconomic scenarios (I and II) with the near-natural existing condition (EC) at a monthly time scale. The percentage of change in relation to EC is shown in brackets. Changes larger than $25 \%$ (of any sign) are denoted by an asterisk.

\begin{tabular}{|c|c|c|c|}
\hline Time period & $\begin{array}{c}\text { EC } \\
1943-2008\end{array}$ & $\begin{array}{l}\text { Scenario-I } \\
\text { 2015-2051 }\end{array}$ & $\begin{array}{l}\text { Scenario-II } \\
2015-2051\end{array}$ \\
\hline \multicolumn{4}{|c|}{ Average flow conditions } \\
\hline MADIS & 1167.4 & $1016.1(-13.0)$ & $793.7(-32.0)^{*}$ \\
\hline Q50 & 1177.8 & $998.0(-15.3)$ & $781.7(-33.6)^{*}$ \\
\hline Range & 1604.8 & $1416.2(-11.8)$ & $1122.9(-30.0)^{*}$ \\
\hline CVinter & 0.35 & $0.44(27.8)^{*}$ & $0.37(5.8)$ \\
\hline CVintra & 0.90 & $0.89(-1.0)$ & $0.83(-7.3)$ \\
\hline \multicolumn{4}{|c|}{ High flow conditions } \\
\hline MH 13 & 2544.8 & $2161.2(-15.1)$ & $1832.2(-28.0)^{*}$ \\
\hline CVH & 0.88 & $0.92(5.1)$ & $0.89(1.1)$ \\
\hline IH & 3.25 & $3.42(5.2)$ & $3.48(7.1)$ \\
\hline AMAX/Q50 & 1.72 & $1.82(5.3)$ & $1.91(10.5)$ \\
\hline \multicolumn{4}{|c|}{ Low flow conditions } \\
\hline ML 13 & 389.1 & $386.3(-0.7)$ & $351.6(-9.6)$ \\
\hline CVL & 0.63 & $0.67(5.8)$ & $0.63(-0.9)$ \\
\hline IL & 0.19 & $0.20(3.1)$ & $0.25(28.3)^{*}$ \\
\hline AMIN/Q50 & 0.36 & $0.40(9.4)$ & $0.47(29.3)^{*}$ \\
\hline
\end{tabular}


Table 4. Peak flow $\left(\mathrm{m}^{3} \mathrm{~s}^{-1}\right)$ before the date the satellite image was taken (April each year), with the corresponding extent of inundated mulapos $\left(\mathrm{km}^{2}\right)$ and volume of water in the floodplain $\left(\mathrm{km}^{3}\right)$, from 2001 to 2011, calculated in a GIS using images from Landsat 7 and SRTM digital elevation model (DEM).

\begin{tabular}{llll} 
Year & $\begin{array}{l}\text { Peak } \\
\text { Flow } \\
\left(\mathrm{m}^{3} \mathrm{~s}^{-1}\right)\end{array}$ & $\begin{array}{l}\text { Mulapos } \\
\begin{array}{l}\text { Area } \\
\left(\mathrm{km}^{2}\right)\end{array}\end{array}$ & $\begin{array}{l}\text { Flood Volume } \\
\left(\mathrm{km}^{3}\right)\end{array}$ \\
\hline 2000 & 4375.1 & 1076.3 & 1161.8 \\
2001 & 4149.3 & 1857.4 & 2298.8 \\
2002 & 2005.4 & 667.0 & 547.6 \\
2003 & 4746.2 & 1978.6 & 2391.1 \\
2004 & 4158.3 & 750.0 & 917.9 \\
2005 & 1553.9 & 296.1 & 555.9 \\
2006 & 3168.8 & 1014.1 & 1061.5 \\
2007 & 5564.0 & 1400.9 & 1574.8 \\
2008 & 4159.4 & 1037.3 & 1170.0 \\
2009 & 6364.9 & 1663.1 & 1863.7 \\
2010 & 5704.4 & 1229.2 & 1395.9 \\
2011 & 4873.6 & 1244.3 & 1313.3 \\
\hline
\end{tabular}


Table 5. Parameters of the Area-Duration curves (AD curves); Estimated Annual Habitat $(\mathrm{EAH})$, index regarding high flow events (Index-H), trimmed mean, and index regarding low flow events (Index-L).

\begin{tabular}{llllll} 
& EC & Scen.1 & Change & Scen.2 & Change \\
\hline EAH & 103295 & 89206 & $14 \%$ & 80881 & $22 \%$ \\
Index-H & 2076 & 2189 & $-5 \%$ & 2121 & $-2 \%$ \\
Trimmed mean & 1016 & 847 & $17 \%$ & 758 & $25 \%$ \\
Index-L & 331 & 209 & $37 \%$ & 219 & $34 \%$ \\
\hline
\end{tabular}

Fig. 1. The scenario approach is illustrated by the principle for creation of future scenarios (modified from Grunewald \& Bastian, 2012).

Development of future scenarios

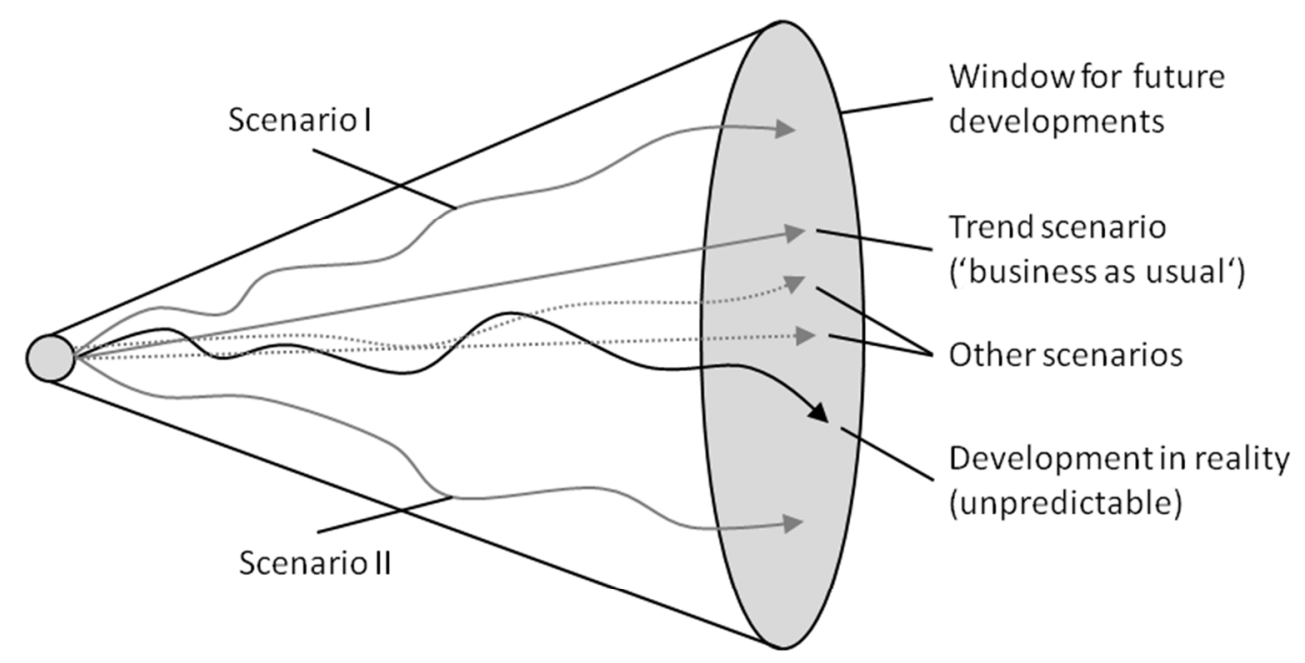

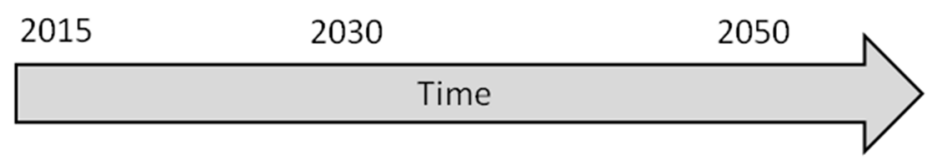


Fig. 2. Methodological framework used in the creation of future scenarios of climatic and socioeconomic change. The three plots show examples of three types of hydrographs (dates from January to December).

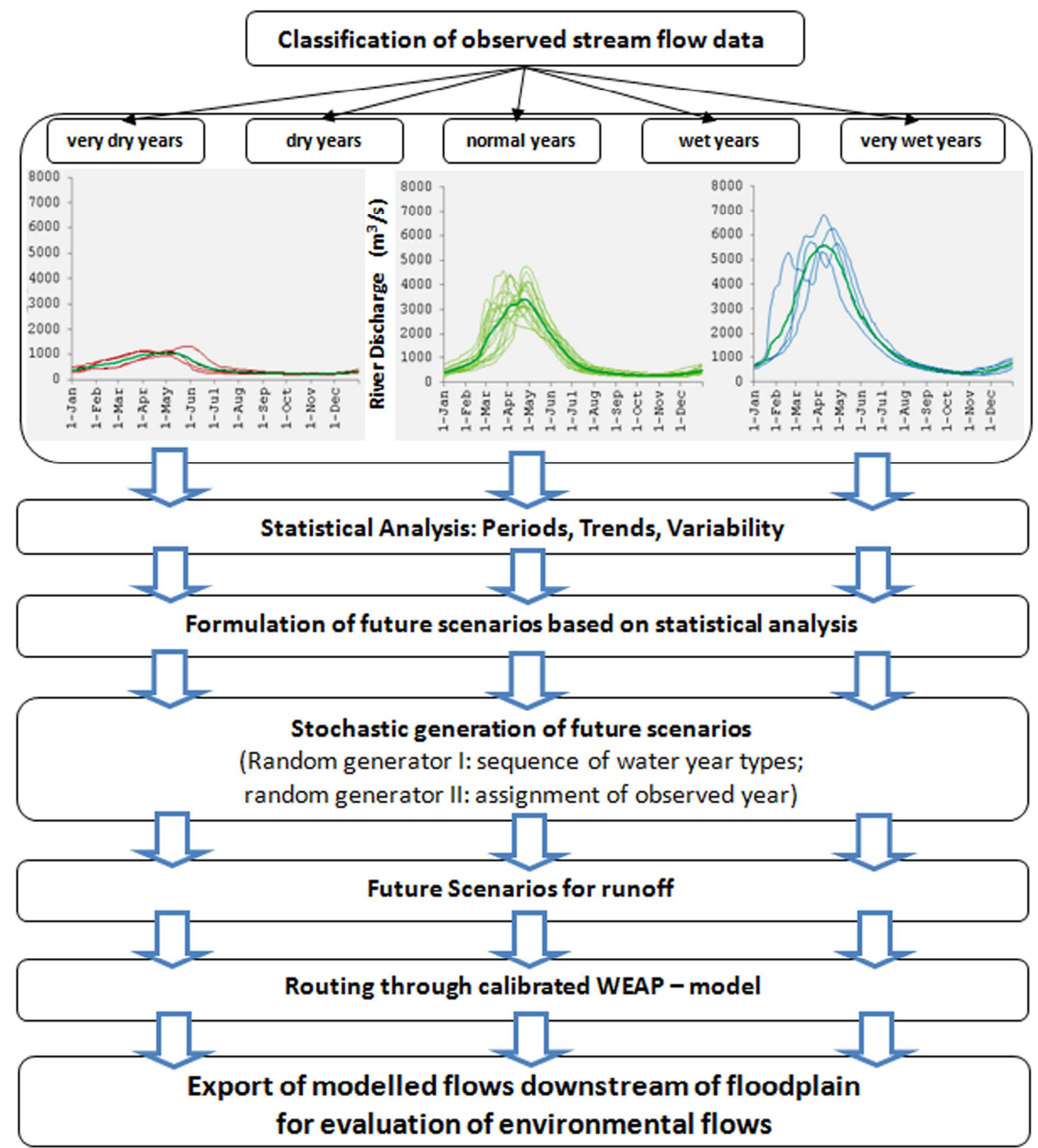


Fig. 3. Time series of river flow from 1965-66 to 1999-2000, where four components of the hydrograph were identified for the calculation of Environmental Flow Components (EFC); i.e., large floods, small floods, high-flow pulses and low flows.

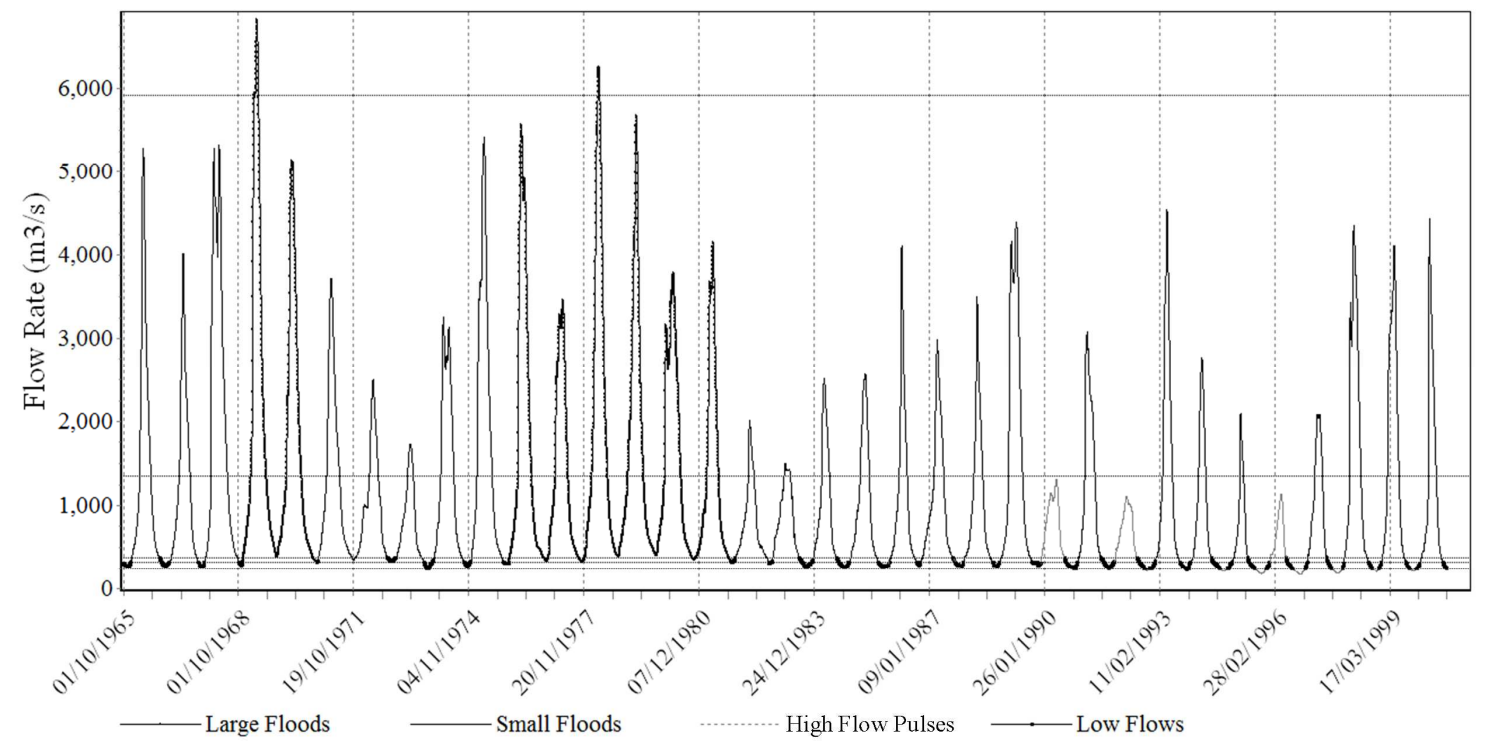

Fig. 4. A) Box-plot for the non-parametric comparison of river flows $\left(\mathrm{m}^{3} \mathrm{~s}^{-1}\right.$, in Log-scale) between the existing condition (observation) and the two scenarios of climatic and socioeconomic change, i.e. SC-I and SC-II. The whiskers indicate the maximum and minimum flows, the boxes indicate the 25th and 75th percentile, and the mean flow is the solid horizontal line, for each of the time periods. B) Comparison of annual hydrographs of mean monthly flow $\left(\mathrm{m}^{3} \mathrm{~s}^{-1}\right.$, in Log-scale) for the observed data and the two scenarios.
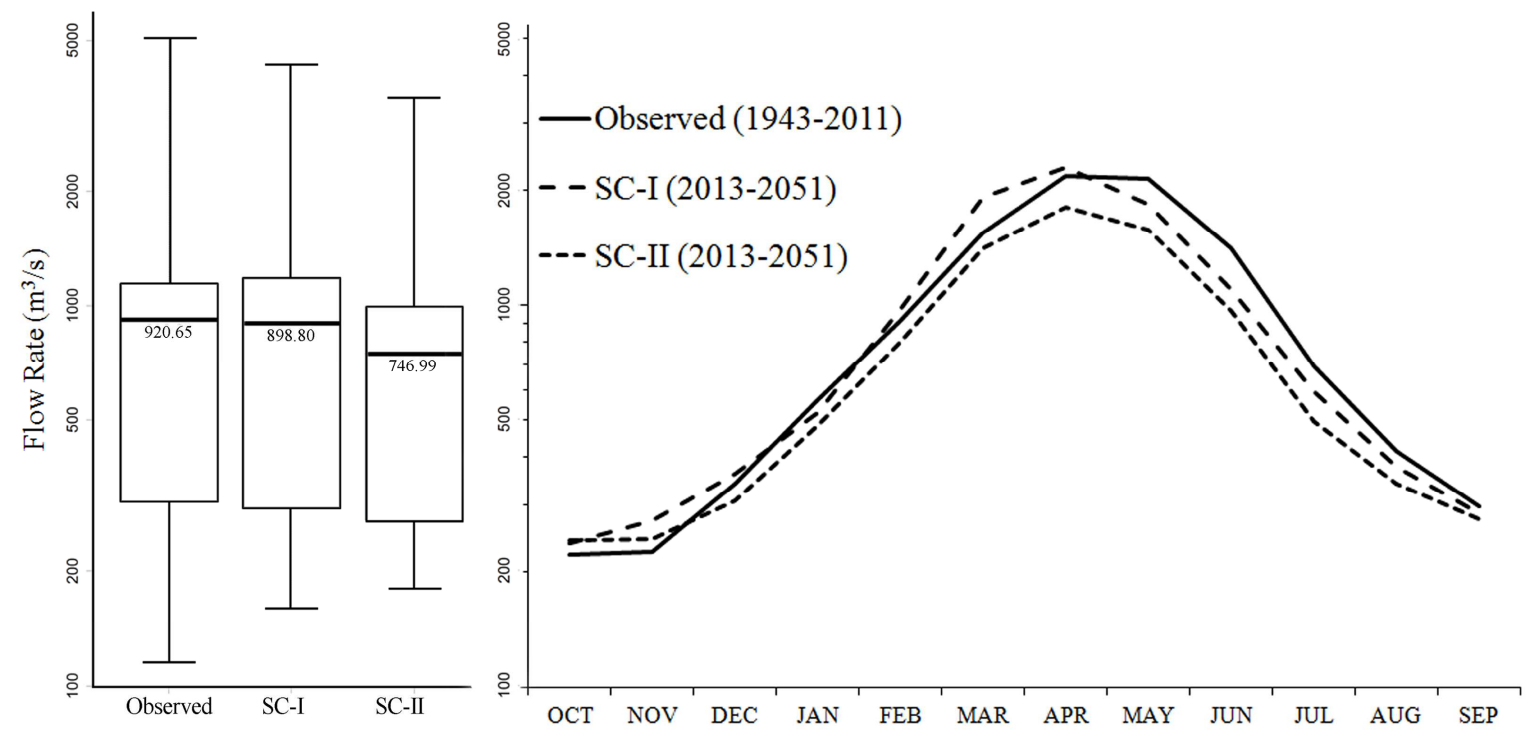
Fig. 5. Area-Duration curves (AD curves) for the comparison between the non-regulated existing conditions and those expected for Scenario I (upper plot) and Scenario II (lower plot), in terms of the exceedance probability for the inundated area of the mulapos. The solid red line (lower solid line) shows the exceedance probability of the mulapos area being inundated under a given scenario; the dotted red lines represent the confidence limits of 5\% and $95 \%$. Likewise, the solid blue line (upper solid line) and dotted blue lines represents similar values for the existing conditions (EC). (To understand the references to colour in this figure legend, the reader is referred to the web version of this article.)
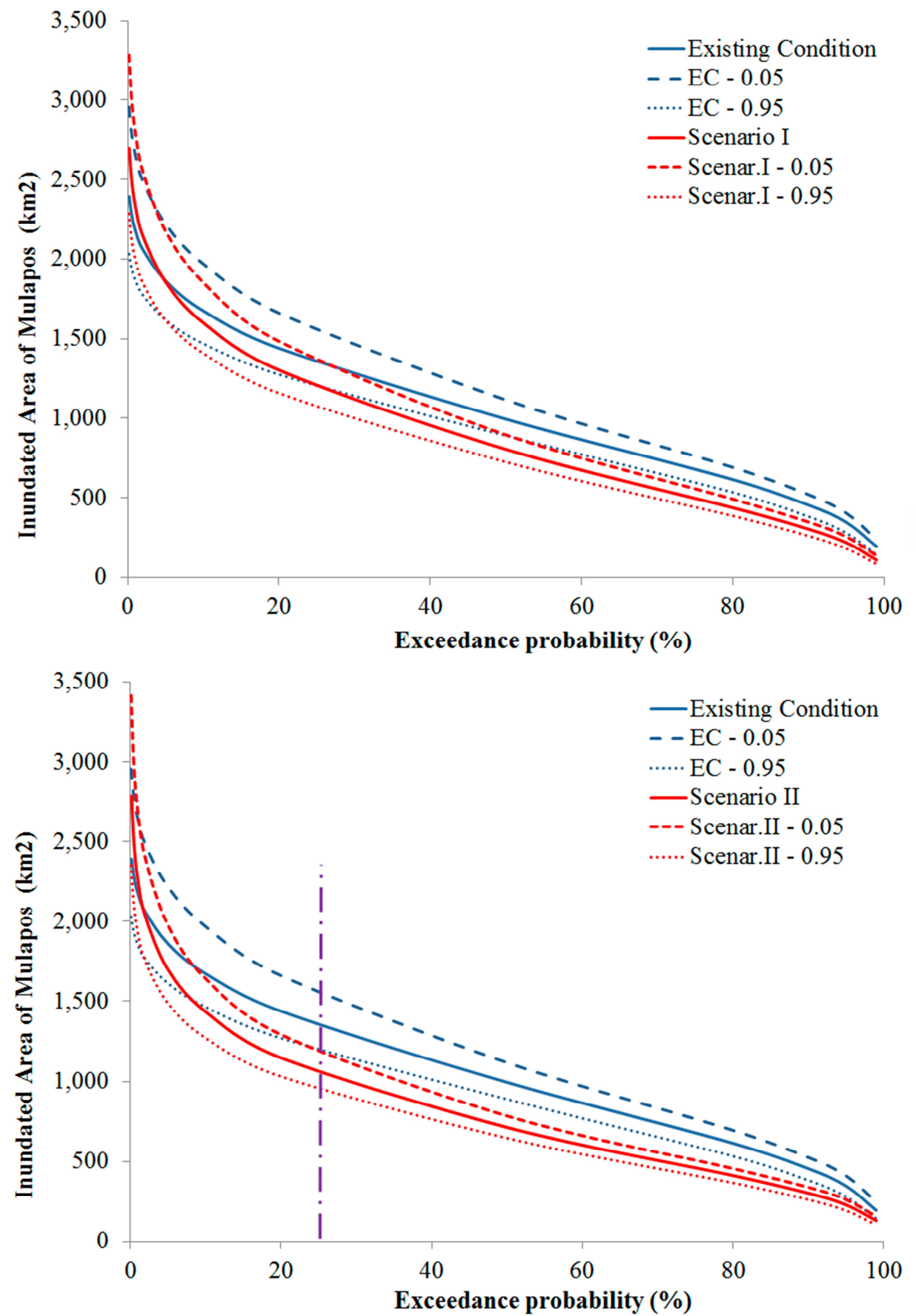
Appendix 1.

Criteria for the classification of water years, providing the baseline for scenario development. The criteria are derived from the statistical analysis of the runoff data as well as from observations from Landsat 7 images.

\begin{tabular}{ccccc}
$\begin{array}{c}\text { Class/ } \\
\text { Criteria }\end{array}$ & $\begin{array}{c}\text { Flood volume } \\
\left(\mathrm{km}^{3}\right)\end{array}$ & $\begin{array}{c}\mathrm{HQ} \\
\left(\mathrm{m}^{3} / \mathrm{s}\right)\end{array}$ & $\begin{array}{c}\mathrm{MQ} \\
\left(\mathrm{m}^{3} / \mathrm{s}\right)\end{array}$ & $\begin{array}{c}\text { Physical } \\
\text { (Landsat 7) }\end{array}$ \\
\hline $\begin{array}{c}\text { very dry year } \\
\text { dry year }\end{array}$ & 0 & $<1350$ & - & no flooding \\
normal year & $7.5-17.5$ & $3000-5000$ & $\begin{array}{c}\mathrm{MQ}=\mathrm{MQ} \\
\pm 0.25 \mathrm{MQmean}\end{array}$ & $\begin{array}{c}- \\
\text { wet year }\end{array}$ \\
$17.5-30$ & $<5000$ & $\mathrm{MQ}>$ MQmean & $\begin{array}{c}\text { no spill into Lake } \\
\text { Liambezi } \\
\text { flooding with spill } \\
\text { into Lake Liambezi }\end{array}$ \\
\hline
\end{tabular}




\section{Appendix 2.}

Simplified scheme of the WEAP model for the Caprivi-Chobe Floodplain. Displayed are the major elements, which are represented as nodes within WEAP. The red triangles (not relevant for the WEAP model) represent river gauges on the river Kwando/Linyanti/Chobe.

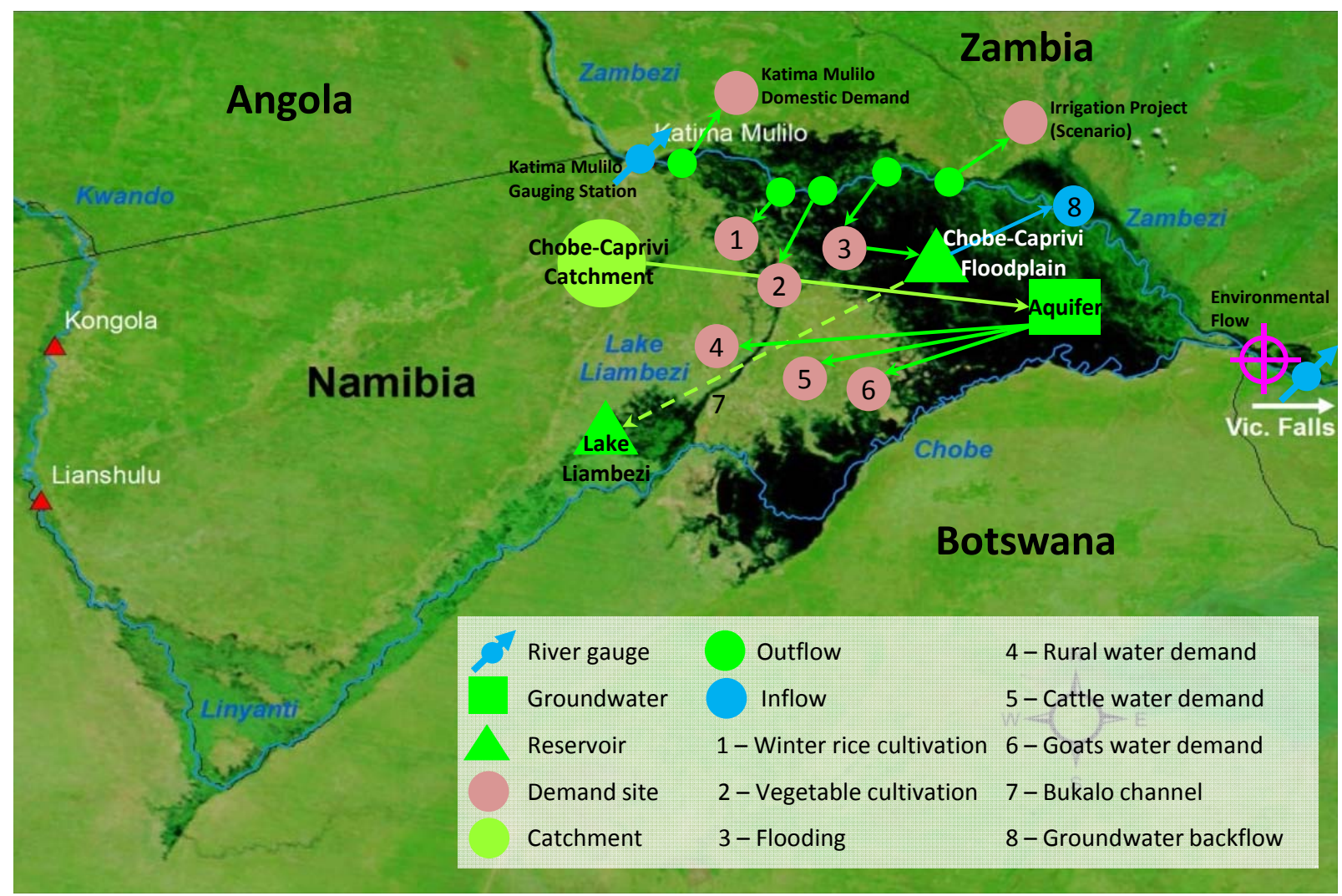


Appendix 3. Assumptions made for the creation of future scenarios. The assumptions are derived from statistical analysis, institutional reports and previous scientific studies. Within the model, each socioeconomic scenario group (a) is modeled with each of the climate scenarios (b). For the presented research, two scenarios were selected as representative scenarios for the determination of environmental flows.

\section{a) Socioeconomic scenarios}

\begin{tabular}{|l|c|c|}
\hline $\begin{array}{l}\text { scenario } \\
\text { group no. }\end{array}$ & scenario group name & explanation \\
\hline I & Climate & $\begin{array}{c}\text { Only climate scenarios are modeled; socio- } \\
\text { economy remains at status quo }\end{array}$ \\
\hline II & climate and socio-economy & $\begin{array}{c}\text { Climate scenarios and predicted socio- } \\
\text { economic developments are modeled }\end{array}$ \\
\hline III & $\begin{array}{c}\text { climate and socio-economy } \\
-10 \%\end{array}$ & $\begin{array}{c}\text { Same as II, but an additional decrease of inflow } \\
\text { of 10 \% of the stream flow at Katima Mulilo } \\
\text { into the catchment, because demand increase } \\
\text { upstream is incorporated }\end{array}$ \\
\hline IV & $\begin{array}{c}\text { climate, socio-economy - } \\
10 \% \text { and adaptation }\end{array}$ & $\begin{array}{c}\text { Same as III, but with implemented adaptation } \\
\text { strategies modeled }\end{array}$ \\
\hline V & $\begin{array}{c}\text { climate, socio-economy } \\
\text { and adaptation }\end{array}$ & $\begin{array}{c}\text { Same as II, but with implemented adaptation } \\
\text { strategies modeled }\end{array}$ \\
\hline
\end{tabular}

Growth rates for socio-economic development: i) Population growth (urban areas) $=2.7 \%$ (DWA, 2005, 2008); ii) Population growth (rural) = 1.3 \% (DWA, 2005, 2008; World Bank 2010); iii) Livestock growth $=2 \%$ (BGR, 2005; World Bank 2010); and iv) Agricultural development (irrigation) $=2.2 \%$ (DWA, 2005, 2008).

\section{b) Climatic scenarios}

\begin{tabular}{|c|c|c|c|c|}
\hline & $\begin{array}{l}2012- \\
2015\end{array}$ & $\begin{array}{l}2015- \\
2033\end{array}$ & $\begin{array}{c}2033- \\
2051\end{array}$ & Comment \\
\hline $\mathbf{I}$ & & & & $\begin{array}{l}\text { Wet cycle ends 2015; then dry cycle, then again wet } \\
\text { cycle }\end{array}$ \\
\hline II & & & & $\begin{array}{c}\text { As for } 1945 \text { to 1980, one wet cycle followed by } \\
\text { another }\end{array}$ \\
\hline III & 5 & 5 & 5 & Same as (I), but increased variability (5\%) \\
\hline IV & 5 & 5 & 5 & Same as (II), but increased variability (5\%) \\
\hline $\mathbf{V}$ & 10 & 10 & 10 & Same as (I), but increased variability (10\%) \\
\hline VI & 10 & 10 & 10 & Same as (II), but increased variability (10\%) \\
\hline VII & & & & Worst case; 2 dry periods follow each other \\
\hline VIII & 5 & 5 & 5 & Worst case with increased variability (5\%) \\
\hline IX & & & & Probabilities of each group averaged over all years \\
\hline $\mathbf{X}$ & 5 & 5 & 5 & $\begin{array}{c}\text { Probabilities of each group averaged over all years } \\
\text { with increased variability (5\%) }\end{array}$ \\
\hline
\end{tabular}

Summary of the approaches for the creation of the 10 future scenarios. Codes: blue, wet cycle; red, dry cycle; purple, no cycle assumed; numbers, increased variability of extreme events in [\%]. 
Appendix 4.

Location of Mulapos in the Caprivi-Chobe wetlands. Blue colours indicate the presence of water. The bright blue coarse lines indicate the main rivers, i.e. Chobe and Zambezi, respectively. Darker blue pieces correspond to the location of the mulapos.

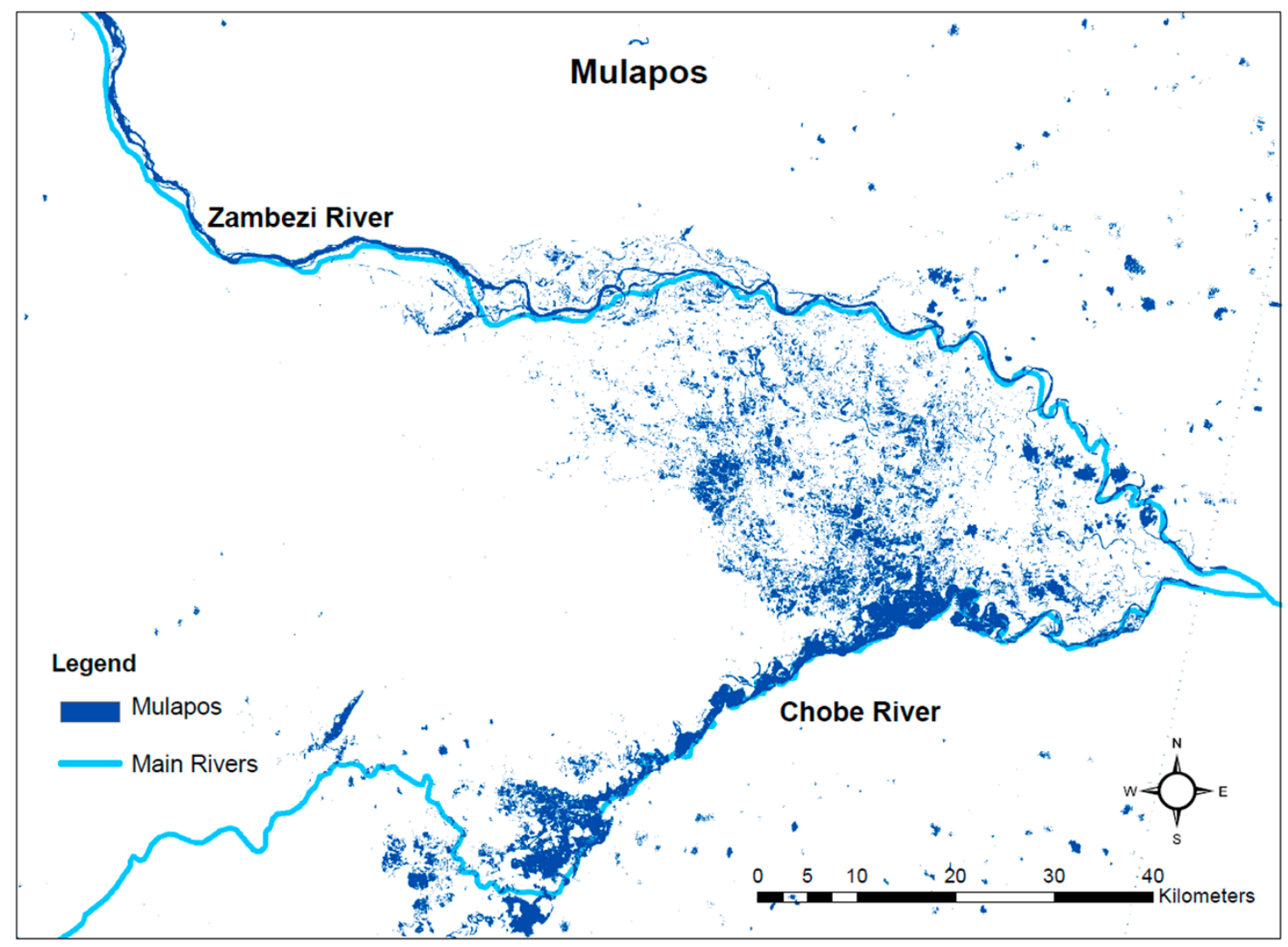

